\title{
Carbon-saturated COH fluids in the upper mantle: a review of high-pressure and high-temperature ex situ experiments
}

\author{
Carla Tiraboschi ${ }^{1}$, Francesca Miozzi $^{2}$, and Simone Tumiati ${ }^{3}$ \\ ${ }^{1}$ Institut für Mineralogie, Westfälische Wilhelms-Universität Münster, 48149 Münster, Germany \\ ${ }^{2}$ Earth and Planets Laboratory, Carnegie Institution for Science, Washington, DC 20015, USA \\ ${ }^{3}$ Dipartimento di Scienze della Terra, Università Degli Studi di Milano, Via Mangiagalli 34, 20133 Milan, Italy
}

Correspondence: Carla Tiraboschi (ctirabos@uni-muenster.de)

Received: 25 June 2021 - Revised: 8 November 2021 - Accepted: 9 December 2021 - Published: 26 January 2022

\begin{abstract}
High-pressure $\mathrm{COH}$ fluids have a fundamental role in a variety of geological processes. Their composition in terms of volatile species can control the solidus temperature and carbonation/decarbonation reactions, as well as influence the amount of solutes generated during fluid-rock interaction at depth. Over the last decades, several systems have been experimentally investigated to unravel the effect of $\mathrm{COH}$ fluids at upper-mantle conditions. However, fluid composition is rarely tackled as a quantitative issue, and rather infrequently fluids are analyzed in the same way as the associated solid phases in the experimental assemblage. A comprehensive characterization of carbon-bearing aqueous fluids in terms of composition is hampered by experimental difficulties in synthetizing and analyzing high-pressure fluids without altering their composition upon quenching.

Recently, improved techniques have been proposed for the analyses of experimental carbon-saturated $\mathrm{COH}$ fluids, leading to a significant advancement in synthetic fluid characterization. Here, we present a review of carbon-bearing aqueous fluid experiments conducted at lower-crust and upper-mantle $P-T$ (pressure and temperature) conditions, in which fluids have been characterized quantitatively through ex situ techniques. We review the experimental background of the most commonly employed thermodynamic models for $\mathrm{COH}$ fluids, together with the techniques to synthetize them and analyze their composition when the fluid coexists with solid phases. We highlight how a quantitative approach to $\mathrm{COH}$ fluid analyses is a fundamental step to understand the effect of these fluids at upper-mantle conditions and to provide a strong experimental foundation to thermodynamic models to ultimately unravel the deep cycling of elements.
\end{abstract}

\section{Introduction}

Aqueous fluids are involved in many geological processes, from controlling the location and extent of melting to hydrothermal ore genesis, earthquake generation, arc volcanism, and rock-forming processes in general (e.g., Green, 1973; Tatsumi et al., 1986; Taylor and McLennan, 1995; Poli and Schmidt, 2002). In subduction zones, aqueous fluids derived from devolatilization processes of the oceanic lithosphere and its sedimentary cover (Schmidt and Poli, 2014, and references therein) are major vectors of mass transfer from the slab to the mantle wedge (Kawamoto et al., 2013; Kogiso et al., 1997; Manning, 2004; Sanchez-Valle, 2013; Scambelluri and Philippot, 2001) and contribute to the recycling of elements and their geochemical cycles.
In this setting $\mathrm{CO}_{2}$ is the second most abundant volatile species, as testified by fluid inclusions in mantle wedge peridotites (Andersen and Neumann, 2001; Frezzotti and Touret, 2014; Kawamoto et al., 2013; Scambelluri et al., 2009) and by volcanic arc emissions (Wallace, 2005; Mason et al., 2017). $\mathrm{CO}_{2}$ is transferred from the oceanic lithosphere to the mantle wedge through dissolution of carbonates (Caciagli and Manning, 2003; Sanchez-Valle et al., 2003), diapirism of slab rock (Marschall and Schumacher, 2012; Tumiati et al., 2013), and carbonatitic melts (Hammouda and Keshav, 2015; Poli, 2015; Stagno, 2019). Recent experimental data indicate that the $\mathrm{CO}_{2}$ content fluxing from the slab to the mantle wedge could be higher than previously thought due to the effect of silicate dissolution in the presence of graphite, 
independently from carbonates occurrence (Tumiati et al., 2017). Graphite, previously considered a refractory phase (e.g., Manning et al., 2013), can effectively increase the $\mathrm{CO}_{2}$ budget of the mantle wedge by oxidation processes favored by the dissolution of minerals such as forsterite, enstatite (Tiraboschi et al., 2018), and quartz (Tumiati et al., 2017).

Graphite is brought to depth as carbonaceous material in subducted sedimentary rocks and exhibits a progressive increase in crystallinity with pressure and temperature, from poorly crystallized to almost crystalline graphite (e.g., Beyssac et al., 2002). These forms of carbon are commonly identified as disordered graphitic carbon (Aoya et al., 2010; Beyssac and Rumble, 2014) and may be representative of carbonaceous material at forearc to sub-arc metamorphic conditions. At high temperature and pressure conditions, up to approximately $5 \mathrm{GPa}$, crystalline graphite is considered the most common form of carbon (Beyssac et al., 2002) before its transition to diamond (e.g., Day, 2012).

The important role of graphite, and its variable degrees of crystallinity in the subduction zone, has been also pointed out by recent studies (Tumiati et al., 2020; Vitale Brovarone et al., 2020). For instance, Tumiati et al. (2020) showed that in subducted sediments flushed by aqueous fluids, the removal of disordered graphitic carbon is more efficient compared to crystalline graphite. By considering disordered graphitic carbon as a proxy for subducted organic matter, the authors suggested that carbon can be effectively removed from the subducting slab, prompting metasomatic processes in the mantle wedge. Vitale Brovarone et al. (2020) observed an analogous process in blueschist facies rocks from Alpine Corsica and the Western Alps, where subducted carbonaceous material is mobilized at forearc conditions by channelized fluid pathways.

The presence of graphite in rock assemblages brings strong constraints to possible $\mathrm{COH}$ fluid compositions (Holloway, 1984). Conventional thermodynamic modeling (e.g., PERPLE_X: Connolly and Cesare, 1993; COH: Huizenga, 2001; Gfluid: Zhang and Duan, 2009) allows for the retrieval of the volatile speciation of the $\mathrm{COH}$ fluid associated with graphite or diamond as a function of $P$ (pressure), $T$ (temperature), and $f \mathrm{O}_{2}$. However, these models rely on equations of state (EoS) that only consider pure molecular species (e.g., $\mathrm{H}_{2} \mathrm{O}, \mathrm{CO}_{2}, \mathrm{CH}_{4}, \mathrm{CO}$ ). Recent advances in thermodynamic modeling, represented for instance by the Deep Earth Water (DEW) model (Huang and Sverjensky, 2019; Sverjensky et al., 2014b), allow not only molecular species but also charged species to be investigate, such as carbonate or bicarbonate ions and organic dissolved compounds (Pan and Galli, 2016; Sverjensky et al., 2014a; Tiraboschi et al., 2018). However, additional constraints on the speciation of solutes are required to properly calibrate thermodynamic models in more complex systems.

In this review, we will present recent experimental data on carbon-saturated $\mathrm{COH}$ fluids. We will address the following: (i) the volatile speciation of graphite-saturated $\mathrm{COH}$ flu-

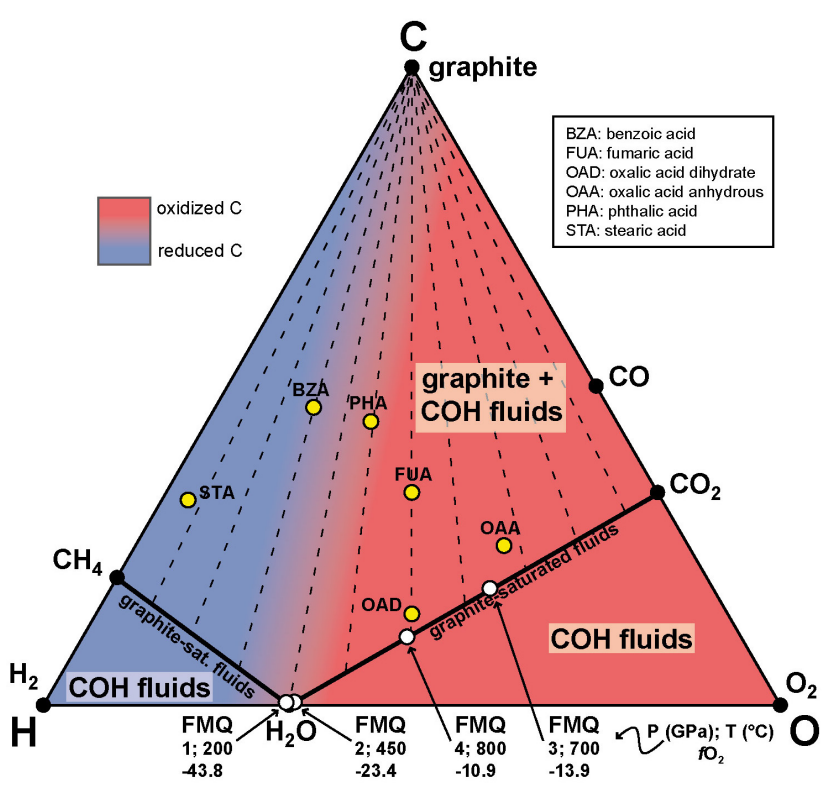

Figure 1. Ternary $\mathrm{C}-\mathrm{O}-\mathrm{H}$ diagram. Black dots: main $\mathrm{COH}$ volatile species; yellow dots: organic compounds employed in the literature to investigate $\mathrm{COH}$ fluids; white dots: $\mathrm{COH}$ volatile composition at oxygen fugacity conditions fixed by the fayalite-magnetite-quartz (FMQ) buffer at fixed pressure and temperature. Oxygen fugacity values are reported as $\log f \mathrm{O}_{2}$.

ids (hereafter GCOH fluids); (ii) the volatile speciation and solute content of $\mathrm{GCOH}$ fluids in equilibrium with different solid phases; and (iii) the different dissolution behavior of disordered graphitic carbon and crystalline graphite in aqueous fluids.

\subsection{GCOH fluids: thermodynamic constraints and theoretical background on molecular neutral species}

The volatile speciation in the pure $\mathrm{COH}$ system is often represented by means of ternary $\mathrm{C}-\mathrm{O}-\mathrm{H}$ chemographic diagrams, in which the main molecular neutral species (i.e., $\mathrm{H}_{2} \mathrm{O}, \mathrm{CO}_{2}, \mathrm{CH}_{4}, \mathrm{CO}, \mathrm{H}_{2}$, and $\mathrm{O}_{2}$ ) are plotted together with the solid carbon phase (i.e., graphite or diamond). The $\mathrm{COH}$ ternary diagram presents a two-phase field delimited from a one-phase field by the graphite-saturation surface (Connolly, 1995; bold solid line in Fig. 1), which is the locus of points representing the composition of a $\mathrm{COH}$ fluid phase coexisting with a solid carbon phase, in this case graphite. The position of the graphite-saturation surface varies with pressure and temperature: decreasing temperatures shift the curve toward $\mathrm{H}_{2} \mathrm{O}$, while decreasing pressure leads to the opposite effect (Huizenga, 2011).

Considering the Gibbs phase rule the two-phase field, graphite $+\mathrm{COH}$ fluid, is univariant if pressure and temperature are fixed. Accordingly, the composition of a $\mathrm{COH}$ fluid in equilibrium with graphite would lie on the tie-line 
(dashed lines in Fig. 1) that connects the graphite vertex to the graphite-saturation surface. As graphite is a phase of fixed composition, the composition of the $\mathrm{COH}$ fluid would lie on the graphite-saturation surface.

In a closed fluid system (i.e., no mass is gained or lost by the system), the $\mathrm{GCOH}$ fluid speciation will be determined uniquely by the $\mathrm{H} / \mathrm{O}$ molar ratio. This ratio can be expressed by the variable $X(O)$ (Connolly, 1995; Labotka, 1991), i.e., the atomic fraction of oxygen relative to oxygen + hydrogen, which is in turn related to oxygen fugacity $\left(f \mathrm{O}_{2}\right)$. The $\mathrm{GCOH}$ systems can be described through the reactions occurring among the main species within the diagram and their relative equilibrium constants (French, 1966; Ohmoto and Kerrick, 1977):

$$
\begin{aligned}
2 \mathrm{H}_{2}+\mathrm{O}_{2} & =\mathrm{H}_{2} \mathrm{O}, K_{1}=f \mathrm{H}_{2} \mathrm{O} / f \mathrm{O}_{2} \cdot f \mathrm{H}_{2}^{2}, \\
\mathrm{C}+\mathrm{O}_{2} & =\mathrm{CO}_{2}, K_{2}=f \mathrm{CO}_{2} / a_{\mathrm{c}} \cdot f \mathrm{O}_{2}, \\
2 \mathrm{C}+\mathrm{O}_{2} & =2 \mathrm{CO}, K_{3}=f \mathrm{CO}^{2} / a_{\mathrm{c}}^{2} \cdot f \mathrm{O}_{2}, \\
\mathrm{C}+2 \mathrm{H}_{2} & =\mathrm{CH}_{4}, K_{4}=f \mathrm{CH}_{4} / a_{\mathrm{c}} \cdot f \mathrm{H}_{2}^{2},
\end{aligned}
$$

where $f i$ is the fugacity of the species $i$ (e.g., $\mathrm{H}_{2} \mathrm{O}, \mathrm{CO}_{2}$, $\left.\mathrm{CH}_{4}\right)$ and $a_{\mathrm{c}}$ is the activity of the carbon solid phase $\left(a_{\mathrm{c}}=1\right.$ in $\mathrm{GCOH}$ fluids). The four equations present six unknowns, i.e., the fugacities of $\mathrm{H}_{2}, \mathrm{O}_{2}, \mathrm{H}_{2} \mathrm{O}, \mathrm{CO}_{2}, \mathrm{CO}$, and $\mathrm{CH}_{4}$. To solve the system two compositional constraints are required. The first constraint is given by the assumption that the total fluid pressure is equal to the sum of partial pressures of the fluid volatile species:

$$
P_{\text {fluid }}=P \mathrm{H}_{2} \mathrm{O}+P \mathrm{O}_{2}+P \mathrm{H}_{2}+P \mathrm{CO}_{2}+P \mathrm{CO}+P \mathrm{CH}_{4} \text {. }
$$

Moreover, the sum of all molar fractions of the fluid must equal a unit:

$$
X \mathrm{H}_{2} \mathrm{O}+X \mathrm{CO}_{2}+X \mathrm{CO}+X \mathrm{H}_{2}+X \mathrm{O}_{2}+X \mathrm{CH}_{4}=1 .
$$

Therefore, the total fluid pressure can be expressed as follows:

$$
\begin{aligned}
P_{\text {fluid }} & =\left(f \mathrm{H}_{2} \mathrm{O} / X \mathrm{H}_{2} \mathrm{O}\right)+\left(f \mathrm{CO}_{2} / X \mathrm{CO}_{2}\right) \\
& +(f \mathrm{CO} / X \mathrm{CO})+\left(f \mathrm{H}_{2} / X \mathrm{H}_{2}\right) \\
& +\left(f \mathrm{O}_{2} / X \mathrm{O}_{2}\right)+\left(f \mathrm{CH}_{4} / X \mathrm{CH}_{4}\right)
\end{aligned}
$$

The additional constraint needed to solve the system, at fixed pressure and temperature, is given by $f \mathrm{O}_{2}$, which can be controlled in experimental runs employing redox buffering assemblages (e.g., fayalite-magnetite-quartz (FMQ), hematite-magnetite (HM)), also known as oxygen buffers. Experimentally controlling the $f \mathrm{O}_{2}$ allows us to determine the composition of carbon-saturated fluids by means of thermodynamic modeling since the composition of the fluid will be uniquely defined at fixed $P$ and $T$ (white dots in Fig. 1). Nevertheless, this approach relies on some concepts which have to be considered when the $\mathrm{COH}$ volatile speciation is calculated (French, 1966): i. The calculation is valid only for a homogeneous $\mathrm{COH}$ fluid and does not apply if additional elements are present in the gas (e.g., $\mathrm{N}, \mathrm{S}$, and $\mathrm{Cl}$ ) or if the fluid reacts with the associated mineral assemblage, except for graphite. The presence of solutes will increase the solvus temperature of the system (e.g., Bowers and Helgeson, 1983) and will affect the activity of $\mathrm{H}_{2} \mathrm{O}$ (e.g., Aranovich and Newton, 1997; Tumiati et al., 2017).

ii. The gas phase is assumed to exhibit ideal behavior under all conditions.

iii. The fluid is assumed to be in continuous equilibrium with graphite. Disequilibria with graphite, or the presence of disordered graphite, will change the thermodynamic properties of the fluid (see Tumiati et al., 2020).

iv. The uncertainty of the $f \mathrm{O}_{2}$ calculated with thermodynamic models for different external buffers, such as FMQ or HM, might lead to different results in term of volatile speciation, as $\mathrm{COH}$ fluid composition is extremely sensitive to changes in oxygen fugacity (Huizenga, 2001).

v. The calculation can be performed only in a closed system. The direct application of the results to natural fluid systems, which might not represent closed systems, should be carefully evaluated.

Consequently, for a comprehensive characterization of $\mathrm{COH}$ fluids, these issues must be considered, especially in more complex chemical systems where the combined effect of these factors could significantly affect the volatile speciation.

\subsection{Experimental data behind the thermodynamic modeling}

At the current state thermodynamic modeling represents a viable way to predict fluid speciation for simple chemical systems at specific pressure and temperature conditions, and several programs based on different computational languages are available. The majority of the programs rely on the equilibrium-constant mass balance technique (French, 1966) to perform the calculations. The model is based on the chemical equilibria between the existing species and the relatives' equilibrium constants. The latter can be calculated using different equations, as well as thermodynamic datasets. Assuming ideal mixing a direct relation between the mole fraction and the fugacity of species can be established and used to determine the equilibrium constants (e.g., Huizenga, 2001). Ohmoto and Kerrick (1977) provide a set of $P_{\text {fluid }}-T$ equations for the equilibrium constants with thermodynamic data from previous authors (i.e., Holland, 1965; Huebner, 1971). Furthermore, the same equilibrium constants can be calculated with the Gibbs free energy of the reaction, obtained with the enthalpy, entropy, and isobaric heat capacity of the 
fluid species (Huizenga, 2001, and references therein). Modeling $\mathrm{COH}$ fluids at high-pressure and high-temperature conditions also requires a reliable equation of state. Several formalisms have been developed for fluid phases (e.g., Zhang and Duan, 2009) relying on standard formalisms for the evolution of volume with pressure or combining pressure and temperature. Sometimes temperature can be accounted for in modified versions of standard equations of state (e.g., Fried and Howard, 2000). EoS are usually based on experimental data collected in a limited pressure and temperature range or even obtained a priori and fitted afterward to a specific dataset. For these reasons it represents a significant source of uncertainty in models. In recent years also molecular dynamic (MD) simulations have emerged as a means to study fluid speciation at non-ambient conditions (e.g., Huizenga, 2001; Zhang and Duan, 2009) and generate data to be used for equation state fitting.

Currently, several computer programs (e.g., PERPLE_X: Connolly and Cesare, 1993; COH: Huizenga, 2001; Gfluid: Zhang and Duan, 2009) offer the possibility of calculating $\mathrm{COH}$ fluid speciation at specific pressure and temperature conditions, provided that the system under examination meets the necessary requirements (see Sect. 1.1).

\section{GCOH fluids synthesis and volatile speciation analyses}

Analyzing volatiles at high-pressure and high-temperature conditions is not trivial. A variety of analytical techniques are available and routinely employed for the characterization of solid phases and for the analysis of fluids in natural or synthetic inclusions (Frezzotti et al., 2012; Lamadrid et al., 2014; Li, 2017; Pasteris and Wanamaker, 1988; Pawley et al., 1992; Roedder, 1965). Even though the study of natural fluid systems is of fundamental importance, the trapped fluid may experience different post-entrapment processes, such as $\mathrm{H}$ diffusion through the host mineral (e.g., olivine), or undergo composition modifications upon decompression and cooling. Consequently, the development of experimental and analytical strategies involving synthetic fluids is crucial to provide solid benchmarks for high-pressure fluid characterization.

Over the years different approaches, either in situ or ex situ, have been established. For the purpose of this review, we will briefly mention the most common in situ techniques and then focus solely on the ex situ approach.

In situ techniques (Sanchez-Valle, 2013, and references therein) are generally achieved through hydrothermal diamond anvil cells (HDAC; Bassett et al., 1993; Schmidt and Chou, 2012) associated with different analytical approaches, such as Raman and Fourier transform infrared (FTIR) spectroscopy (e.g., McCubbin et al., 2014; Mysen and Yamashita, 2010). HDAC can be also coupled with laser or synchrotron X-ray spectroscopies (Louvel et al., 2013; Mookherjee et al.,
2014; Wilke et al., 2012; Zotov and Keppler, 2002). These approaches allow the retrieval of information about the speciation of volatiles directly during the experimental run, together with the speciation of major solutes and trace elements, but do not provide the total amount of volatile present in the experimental charge or the amount of dissolved species in the fluid in terms of molar concentration. This information can be retrieved through ex situ techniques, which provide quantitative analyses of volatile species (e.g., Miozzi and Tumiati, 2020; Tiraboschi et al., 2016; Tumiati et al., 2017) or the concentration of dissolved species in the fluid (e.g., Kessel et al., 2004; Tiraboschi et al., 2018).

Ex situ experimental works on $\mathrm{COH}$ fluids have required the development of original strategies (e.g., Akaishi and Yamaoka, 2000; Chepurov et al., 2012; Matveev et al., 1997; Morgan et al., 1992; Truckenbrodt et al., 1997; Truckenbrodt and Johannes, 1999) to recover the fluid phase from the experimental capsule and measure the fluid composition afterwards through a variety of analytical approaches. $\mathrm{COH}$ fluids can be synthetized in a wide range of $P-T$ composition conditions through piston cylinders and multi-anvil apparatus; however, quenching the fluids to room conditions might represent a drawback. The bulk composition of the quenched fluid in terms of $\mathrm{C}, \mathrm{O}$, and $\mathrm{H}$ is considered to be representative of the experimental $P-T$ conditions when high quench rates are attained (i.e., $>20^{\circ} \mathrm{C} \mathrm{min}^{-1}$; Matveev et al., 1997). Conversely, for low quench rates, possible modifications in the speciation of volatiles can only be ruled out by confronting the volatile speciation with complementary in situ studies (e.g., Schmidt, 2014) or by thermodynamic modeling (see Tiraboschi et al., 2016). Ex situ experiments have the fundamental advantage of allowing the oxygen fugacity conditions to be accurately controlled through the double capsule technique (Eugster, 1957; Eugster et al., 1966), a strategy employed to keep the sample physically separated from the oxygen buffer. This technique consists of employing an inner capsule permeable to hydrogen (e.g., AuPd, AgPd), which contains the sample and the GCOH fluid source (i.e., graphite and a compound that generates a $\mathrm{COH}$ fluid at the experimental conditions). The outer capsule contains the inner capsule, an oxygen buffer, and $\mathrm{H}_{2} \mathrm{O}$. Due to $\mathrm{H}_{2}$ permeability of the capsule material, the hydrogen fugacity conditions $\left(f \mathrm{H}_{2}\right)$ will be the same in the inner and in the outer capsule. Indirectly, also the other species in the $\mathrm{COH}$ fluid will be fixed by the oxygen buffer, including $\mathrm{O}_{2}$. However, as the inner capsule contains a mixed $\mathrm{COH}$ fluid and not pure water only, the $f \mathrm{O}_{2}$ in the inner capsule will be lower compared to the $f \mathrm{O}_{2}$ in the outer capsule (Luth, 1989).

For what concerns fluid sources, different solid organic compounds (e.g., stearic acid, oxalic acid dihydrate) can be employed to generate $\mathrm{COH}$ fluids in experimental runs (see Fig. 1). Usually, the choice of the fluid source depends on the $\mathrm{H} / \mathrm{O}$ ratio, assuming that this ratio will be maintained at the experimental $P-T$ conditions (Table 1) or that the initial 
volatile speciation is adequate to provide the expected equilibrium speciation if oxygen buffers are employed.

The first ex situ analysis of $\mathrm{COH}$ fluids was performed by Holloway et al. (1968). The authors investigated the decomposition of oxalic acid dihydrate $\left(\mathrm{OAD} ; \mathrm{H}_{2} \mathrm{C}_{2} \mathrm{O}_{4} \cdot 2 \mathrm{H}_{2} \mathrm{O}\right)$ in cold seal and internally heated pressure vessels at 0.1 to $0.7 \mathrm{GPa}$ and 500 to $1005^{\circ} \mathrm{C}$. OAD was employed to generate a COH fluid (Boettcher et al., 1973; Eugster et al., 1966; Eugster and Skippen, 1967) as it decomposes at high temperatures to $\mathrm{H}_{2} \mathrm{O}, \mathrm{CO}_{2}$, and $\mathrm{H}_{2}$. After quenching, the capsule was punctured in an evacuated chamber and the fluid was analyzed through a gas chromatograph for $\mathrm{CO}_{2}, \mathrm{CO}$, and $\mathrm{CH}_{4}$.

Eggler et al. (1979) implemented the capsule-piercing technique of Holloway et al. (1968) by modifying the gas chromatograph, using a thermal conductivity detector and an electronic peak integrator. The authors investigated the solubility of $\mathrm{CO}_{2}$ and $\mathrm{CO}$ in different silicate melts synthesized in piston cylinder experiments at $3 \mathrm{GPa}$ and $1700^{\circ} \mathrm{C}$. To extract the fluid, the capsule was placed at the bottom of a vacuum valve connected to a gas chromatograph. The valve was then rapidly closed to puncture the capsule, and the gases were swept to the chromatographic column. The analyzed $\mathrm{CO}_{2}$ concentrations were systematically higher compared to the calculated values through Redlich-Kwong EoS (Redlich and Kwong, 1948). The effect was attributed to CO formation due to low-temperature re-equilibration reactions between graphite and $\mathrm{CO}_{2}$.

Taylor and Green (1987) employed a capsule-piercing device connected to a mass spectrometer to investigate reducing GCOH fluids in the model peridotite system nephelineforsterite-silica. The device was composed of a modified Whitey regulating valve with a redesigned stem tip into a harder needlepoint. To obtain low background levels, especially due to absorbed molecules of $\mathrm{H}_{2} \mathrm{O}$ on the metal surface, the system was evacuated for $12 \mathrm{~h}$ prior to measurements. The technique allowed methane, ethane, and trace amounts of $\mathrm{C}_{3-4}$ hydrocarbons to be measured. The strategy was then described in detail in the work of Taylor and Foley (1989), in which the authors assessed the composition of $\mathrm{COH}$ fluids buffered by $\mathrm{WC}-\mathrm{WO}_{2}$-graphite (WCWO). Experiments were performed at pressures from 0.9 to $3.5 \mathrm{GPa}$ and temperatures from 1000 to $1260^{\circ} \mathrm{C}$. The device allowed $\mathrm{CH}_{4}, \mathrm{H}_{2} \mathrm{O}, \mathrm{C}_{2} \mathrm{H}_{6}$, and $\mathrm{CO}_{2}$ generated from stearic acid $\left(\mathrm{C}_{18} \mathrm{H}_{36} \mathrm{O}_{2}\right)$ in equilibrium with graphite to be analyzed, and it provided a suitable buffering strategy for experiments at reduced oxygen fugacity conditions.

Jakobsson and Oskarsson (1990) modified the vacuum valve of the gas chromatography-thermal conductivity detector (GC-TCD) previously employed by Eggler et al. (1979) by connecting it to a quadrupole mass spectrometer (QMS). The capsule-piercing device was modified to allow the analysis of $\mathrm{H}_{2} \mathrm{O}$ by heating the inlet system to $80^{\circ} \mathrm{C}$. The authors retrieved the speciation of a GCOH fluid at iron-wuestite (IW) oxygen buffer conditions, at pressures from 0.5 to $1 \mathrm{GPa}$ and temperatures from 900 to $1200^{\circ} \mathrm{C}$, analyzing $\mathrm{H}_{2}$,
$\mathrm{CH}_{4}, \mathrm{H}_{2} \mathrm{O}, \mathrm{C}_{2} \mathrm{H}_{6}, \mathrm{CO}$, and $\mathrm{CO}_{2}$ through a Faraday cup detector. Since results were close to the calculated values, the authors suggested that equilibrium was reached during the experimental run and preserved upon quenching. In a subsequent work the same authors (Jakobsson and Oskarsson, 1994) investigated GCOH fluids in equilibrium with graphite from 0.7 to $2 \mathrm{GPa}$ and 1100 to $1500^{\circ} \mathrm{C}$. The detected species were $\mathrm{CO}, \mathrm{CO}_{2}$, and $\mathrm{H}_{2} \mathrm{O}$, while $\mathrm{H}_{2}, \mathrm{CH}_{4}$, and $\mathrm{C}_{2} \mathrm{H}_{6}$ were absent (i.e., below detection limit of $0.1 \mathrm{~mol} \%$ ). Different quench rates showed decreasing $\mathrm{CO}$ with increased quench time, suggesting $\mathrm{CO}_{2}$ formation from $\mathrm{CO}$, as previously proposed by Eggler et al. (1979).

Morgan et al. (1992) employed silica glass capsules and Raman spectroscopy to analyze the $\mathrm{COH}$ fluid generated by thermal dissociation of oxalic acid dihydrate. However, due to the brittleness of the capsule material, the investigated conditions of pressure and temperatures were limited to pressures lower than $0.13 \mathrm{GPa}$ and temperatures below $750^{\circ} \mathrm{C}$. This approach allowed $\mathrm{CO}_{2}, \mathrm{CH}_{4}, \mathrm{CO}$, and $\mathrm{H}_{2}$ to be measured, while $\mathrm{H}_{2} \mathrm{O}$ was estimated through mass balance calculation due to its weak Raman activity.

Matveev et al. (1997) analyzed redox-buffered, graphitesaturated $\mathrm{COH}$ fluids at $2.4 \mathrm{GPa}$ and $1000^{\circ} \mathrm{C}$, over 7.5 orders of magnitude in oxygen fugacity, from -10.9 (CO-CoO buffer) to $24 \log f \mathrm{O}_{2}\left(\mathrm{SiC}-\mathrm{SiO}_{2}-\mathrm{C}\right.$ buffer). The capsule was placed in a helium-flushed piercing device connected to a gas chromatograph. Lines were heated to $150{ }^{\circ} \mathrm{C}$ to prevent water condensation on the tubes. The system was calibrated to analyze $\mathrm{H}_{2} \mathrm{O}, \mathrm{CO}_{2}, \mathrm{C}_{2} \mathrm{H}_{6}, \mathrm{CH}_{4}, \mathrm{CO}$, and $\mathrm{H}_{2}$. Similarly, also Truckenbrodt et al. (1997) employed a gas chromatograph connected to a heated capsule-puncturing system to investigate the $\mathrm{GCOH}$ volatile speciation. The technique allowed them to obtain quantitative analyses of $\mathrm{H}_{2}, \mathrm{CO}, \mathrm{C}_{2} \mathrm{H}_{6}, \mathrm{CO}_{2}$, $\mathrm{CH}_{4}$, and $\mathrm{H}_{2} \mathrm{O}$ generated from different organic compounds $\left(\mathrm{C}_{4} \mathrm{H}_{4} \mathrm{O}_{4}, \mathrm{C}_{9} \mathrm{H}_{10} \mathrm{O}_{2}\right.$, and $\left.\mathrm{C}_{14} \mathrm{H}_{22} \mathrm{O}\right)$ at $1 \mathrm{GPa}$ and $900^{\circ} \mathrm{C}$.

Akaishi et al. (2000) synthesized diamonds from ${ }^{13} \mathrm{C}$ graphitic carbon and oxalic acid dihydrate at $7.7 \mathrm{GPa}$ and $1600^{\circ} \mathrm{C} . \mathrm{H}_{2} \mathrm{O}$ and $\mathrm{CO}_{2}$ were analyzed through a QMS by piercing the platinum capsule. However, $\mathrm{H}_{2} \mathrm{O}$ could not be determined quantitatively because the inlet system was not heated, and thus the removal of the adsorbed water in the vacuum chamber was reported to be particularly difficult.

Dvir et al. (2013) determined the $\mathrm{H}_{2} \mathrm{O}$ and $\mathrm{CO}_{2}$ content at oxidizing conditions, employing diamond traps (Baker and Stolper, 1994; Hirose and Kushiro, 1993) to collect COH fluids from rocking multi-anvil experiments at $6 \mathrm{GPa}$ and $1000^{\circ} \mathrm{C}$. The capsules were frozen at $-90^{\circ} \mathrm{C}$ in liquid nitrogen and open to expose the diamond trap. Fluids were conducted to an infrared gas analyzer by heating the diamond trap at $900^{\circ} \mathrm{C}$ in a quartz tube.

Sokol et al. $(2017 \mathrm{a}, \mathrm{b})$ investigated reduced N-poor and Nrich graphite-saturated $\mathrm{COH}$ fluids at pressures from 5.5 to $7.8 \mathrm{GPa}$ and temperatures ranging from 1100 to $1500^{\circ} \mathrm{C}$, employing a Thermo Scientific FOCUS GS/DSQ II series single quadrupole MS analyzer, previously employed for the anal- 
Table 1. Organic compounds employed in the literature to generate $\mathrm{COH}$ fluids in ex situ experiments.

\begin{tabular}{llrl}
\hline Source of fluid & Chemical formula & $\mathrm{H} / \mathrm{O}$ ratio & References \\
\hline Benzoic acid & $\mathrm{C}_{7} \mathrm{H}_{6} \mathrm{O}_{2}$ & $3: 1$ & Matveev et al. (1997) \\
\hline Docosane & $\mathrm{C}_{22} \mathrm{H}_{46}$ & - & Sokol et al. (2017a, b) \\
\hline Fumaric acid & $\mathrm{C}_{4} \mathrm{H}_{4} \mathrm{O}_{4}$ & $1: 1$ & Eggler et al. (1979); Truckenbrodt et al. (1997) \\
\hline Oxalic acid anhydrous & $\mathrm{H}_{2} \mathrm{C}_{2} \mathrm{O}_{4}$ & $1: 2$ & Tiraboschi et al. (2018) \\
\hline Oxalic acid dihydrate & $\mathrm{H}_{2} \mathrm{C}_{2} \mathrm{O}_{4} \cdot 2 \mathrm{H}_{2} \mathrm{O}$ & $1: 1$ & $\begin{array}{l}\text { Holloway et al. (1968); Boettcher et al. (1973); Holloway and } \\
\text { Reese (1974); Morgan et al. (1992); Rosenbaum and Slagel } \\
\end{array}$ \\
& & & $\begin{array}{l}\text { (1995); Akaishi and Yamaoka (2000); Akaishi et al. (2000); } \\
\text { Tiraboschi et al. (2016); Tumiati et al. (2017, 2020) }\end{array}$ \\
& $\mathrm{C}_{8} \mathrm{H}_{6} \mathrm{O}_{4}$ & $3: 2$ & $\begin{array}{l}\text { Matveev et al. (1997) } \\
\text { Phthalic acid }\end{array}$ \\
\hline Stearic acid & $\mathrm{C}_{18} \mathrm{H}_{36} \mathrm{O}_{2}$ & $\begin{array}{l}\text { Holloway and Jakobsson (1986); Jakobsson and Holloway } \\
\text { (1986); Taylor and Green (1988); Taylor and Foley (1989); } \\
\text { Jakobson and Oskarsson (1990); Matveev et al. (1997); } \\
\text { Akaishi et al. (2000); Sokol et al. (2017a, b) }\end{array}$ \\
\hline
\end{tabular}

ysis of fluid inclusion (Sokol et al., 2014). The gas mixture was extracted by piercing the capsule and then injected into the analytical column at $300^{\circ} \mathrm{C}$. Analytical uncertainty for $\mathrm{H}_{2} \mathrm{O}, \mathrm{NH}_{3}$, and $\mathrm{CO}_{2}$ was less than $10 \%$ and in most cases less than $5 \%$.

Tiraboschi et al. (2016) developed a capsule piercing device connected to a QMS to determine the speciation of major volatiles in synthetic $\mathrm{COH}$ fluids. OAD was employed as the starting material, and experiments were performed at ambient pressure and $250{ }^{\circ} \mathrm{C}$ in single capsules heated in a furnace and at $1 \mathrm{GPa}$ and $800^{\circ} \mathrm{C}$ using a piston cylinder apparatus. The double capsule technique and the rhenium-rhenium oxide (RRO) oxygen buffer were employed to control the redox conditions. After the experimental run, the inner capsule was retrieved and placed in a reactor connected to a QMS. The connecting lines and the reactor were heated to $80^{\circ} \mathrm{C}$ in order to avoid water condensation and to allow all volatiles released from the capsule after the piercing, including $\mathrm{H}_{2} \mathrm{O}$, to be transported to the QMS by the gas carrier. The capsule-piercing technique provided quantitative analysis of the main volatile species in the $\mathrm{COH}$ system: $\mathrm{H}_{2} \mathrm{O}$, $\mathrm{CO}_{2}, \mathrm{CH}_{4}, \mathrm{CO}, \mathrm{H}_{2}$, and $\mathrm{O}_{2}$. The amount of volatiles in the capsule was retrieved using standard gas mixtures, with detection limits lower than $1 \mu$ mol. Moreover, the technique allowed air and/or $\mathrm{N}_{2}$ contained in the capsule or leaking into the line to be measured. Results indicated that the $\mathrm{COH}$ fluid speciation (in terms of neutral molecular species only, such as $\mathrm{H}_{2} \mathrm{O}$ and $\mathrm{CO}_{2}$ ) is preserved during and after quenching as the experimental data closely mimic the results from conventional thermodynamic modeling (see Tiraboschi et al., 2016), both in terms of bulk composition and fluid speciation. The same technique was employed for the characterization of $\mathrm{COH}$ fluid in equilibrium with silicates (Tumiati et al., 2017) and to investigate ordered and disordered graphitic carbon dissolution in subduction zones (Tumiati et al., 2020).

\subsection{GCOH volatile speciation as a highly sensitive oxybarometer}

The link between $\mathrm{COH}$ fluid speciation and the $\mathrm{H} / \mathrm{O}$ molar ratio can be exploited both ways: first, to calculate $\mathrm{COH}$ fluid speciation through thermodynamic models but also to determine the $\mathrm{H} / \mathrm{O}$ molar ratio and consequently the oxygen fugacity of the system under examination. The topic of assessing oxygen fugacity in experimental charges has been already addressed in the past, and oxybarometers of diverse nature have been calibrated. Metallic alloys (e.g., Ir-Fe; Stagno and Frost, 2010), metal-oxide couples (e.g., rutileilmenite; Tao et al., 2017), and mineral assemblages (e.g., olivine-orthopyroxene-spinel; Ballhaus et al., 1991) have been proven to be suitable for the use once the relation between their composition and activity is accurately described (e.g., Balta et al., 2011; Woodland and O’Neill, 1997). Over the years, solid redox sensors have been recognized to be extremely useful; however, the limitations related to their use (e.g., phase transitions, melting) have caused a push toward the definition and calibration of redox sensors based on nonsolid phases (i.e., melts and fluids). For instance, Stagno and Frost (2010) have calibrated an oxybarometer based on the $\mathrm{CO}_{2}$ content of the melt in carbon-carbonate systems, while Miozzi and Tumiati (2020) calibrated an oxybarometer based on the $\mathrm{CO}_{2}$ content of aqueous fluids. The latter exploits the properties of the $\mathrm{GCOH}$ system and establishes a mathematical relation between $X \mathrm{CO}_{2}\left(=\mathrm{CO}_{2} /\left[\mathrm{CO}_{2}+\mathrm{H}_{2} \mathrm{O}\right]\right)$ and the oxygen fugacity through a polynomial equation, whose coefficients were determined for both crystalline graphite and glass-like carbon (see Sect. 4). The susceptibility of $\mathrm{COH}$ 
fluid composition to $f \mathrm{O}_{2}$ conditions makes it an ideal oxybarometer as also the smallest variation is recorded with extreme precision (see Miozzi and Tumiati, 2020).

\section{2 $\mathrm{COH}$ volatile speciation analyses in equilibrium with mantle minerals}

So far, the speciation of $\mathrm{COH}$ fluids in equilibrium with rock assemblages has been often estimated through thermodynamic models that rely on equations of state of simple $\mathrm{H}_{2} \mathrm{O}-$ non-polar gas systems (e.g., equations of state of Connolly and Cesare, 1993, and Zhang and Duan, 2009). These models have been largely employed to constrain the composition of $\mathrm{COH}$ fluids in equilibrium with solid phases (Frost and McCammon, 2008; Goncharov and Ionov, 2012; Malaspina et al., 2010; Malaspina and Tumiati, 2012; Poli et al., 2009; Tumiati et al., 2013; Woodland and Koch, 2003), with the latter being routinely analyzed by means of electron microprobe. Recently, more complex models including dissolved species have been developed (Facq et al., 2014; Galvez et al., 2015; Huang and Sverjensky, 2019; Menzel et al., 2020; Pan et al., 2013; Sverjensky et al., 2014b) to account for the interaction between fluid and coexisting solid phases. However, these models still rely on a very limited experimental dataset due to the lack of quantitative analyses of synthetic $\mathrm{COH}$ fluid in equilibrium with minerals and the relative solubility data for the associated solid phases.

After the pioneering work of Eggler et al. (1979), which investigates the solubility of carbon monoxide in silicate melts, Taylor and Green (1988) analyzed the composition of reduced $\mathrm{COH}$ fluids in equilibrium with a peridotite at 3.5 GPa buffered employing the WCWO buffer (Taylor and Foley, 1989). The capsule-piercing device was heated at $150{ }^{\circ} \mathrm{C}$ which allowed them to determine the $\mathrm{CH}_{4} / \mathrm{H}_{2} \mathrm{O}$ ratio in the fluid to range from 1000 to $1250^{\circ} \mathrm{C}$. This method enabled to assess a rapid change in fluid composition with increasing pressure, from a $\mathrm{CH}_{4}$-dominated fluid to a mainly aqueous fluid.

Dvir and Kessel (2017) investigated unbuffered garnet peridotite at 4-6 GPa and $900-1100^{\circ} \mathrm{C}$ in equilibrium with $\mathrm{H}_{2} \mathrm{O}$ and $\mathrm{CO}_{2}$. The technique allowed them to obtain the $\mathrm{H}_{2} \mathrm{O} / \mathrm{CO}_{2}$ ratio in the fluid or melt but not the total amount of volatiles.

Martin and Hermann (2018) and Sieber et al. (2018, 2020) employed the GC-TCD proposed by Eggler et al. (1979) to quantify the amount of $\mathrm{CO}_{2}, \mathrm{H}_{2} \mathrm{O}$, and alkanes (from methane to hexane) in altered mafic oceanic crust. The measured $\mathrm{XCO}_{2}$ was found to be in agreement but slightly higher compared to thermodynamic modeling, suggesting the influence of additional charged species such as $\mathrm{HCO}_{3}^{-}$(Sverjensky et al., 2014a). Sieber et al. (2020) investigate the carbonation of serpentinites by $\mathrm{GCOH}$ fluids at $1.5-2.5 \mathrm{GPa}$ and $375-700^{\circ} \mathrm{C}$. Time series experiments indicated that after $96 \mathrm{~h}$ at $2 \mathrm{GPa}$ and $600^{\circ} \mathrm{C}$, the carbonation of serpentinites is completed, showing how this process is efficient in seques- tering $\mathrm{CO}_{2}$ from the interacting fluid into newly formed magnesite.

Tumiati et al. (2017) investigate the volatile speciation of $\mathrm{COH}$ fluids in equilibrium with mantle minerals in a carbonate-free compositional range at $800^{\circ} \mathrm{C}$ and pressures of 1 and $3 \mathrm{GPa}$ in order to focus on the role of graphite and silicates. $\mathrm{GCOH}$ fluids were synthesized in equilibrium with minerals representative of subduction mélanges, i.e., Mg-silicates (forsterite + enstatite), representative of the mantle component, and quartz, representative of the sedimentary component. Three different systems were compared: (i) $\mathrm{COH}$, (ii) $\mathrm{SiO}_{2}-\mathrm{COH}$, and (iii) $\mathrm{MgO}-\mathrm{SiO}_{2}-$ $\mathrm{COH}$, all buffered at the same oxygen fugacity conditions (either nickel-nickel oxide (NNO) or fayalite-magnetitequartz (FMQ)). Redox conditions were constrained employing the double capsule technique (Eugster, 1957; Eugster et al., 1966) in order to keep the starting material separated from the oxygen buffer. Depending on the experimental conditions investigated the $f \mathrm{O}_{2}$ conditions in the inner capsule corresponded to -14.28 at $1 \mathrm{GPa}$ and $800^{\circ} \mathrm{C}(\mathrm{NNO}),-14.31$ at $1 \mathrm{GPa}$ and $800^{\circ} \mathrm{C}(\mathrm{FMQ})$, and -11.66 at $3 \mathrm{GPa}$ and $800^{\circ} \mathrm{C}$ (FMQ) (see Tumiati et al., 2017).

The volatile speciation of quenched fluids was analyzed employing the capsule-piercing QMS technique (Tiraboschi et al., 2016), and the results were compared with conventional thermodynamic models using different equations of state and mixing properties of $\mathrm{H}_{2} \mathrm{O}$ and non-polar species.

The measured $X \mathrm{CO}_{2}$ from experiments and the modeled compositions of the $\mathrm{COH}$ fluids coexisting only with graphite overlapped in both experiments buffered with $\mathrm{NNO}$ and FMQ $\left(X \mathrm{CO}_{2}=0.73\right.$ at $1 \mathrm{GPa}$ and $800^{\circ} \mathrm{C}$, NNO; $X \mathrm{CO}_{2}=$ 0.67 at $1 \mathrm{GPa}$ and $800^{\circ} \mathrm{C}, \mathrm{FMQ} ; X \mathrm{CO}_{2}=0.74$ at $3 \mathrm{GPa}$ and $\left.800^{\circ} \mathrm{C}, \mathrm{NNO}\right)$. At the investigated conditions the $\mathrm{COH}$ fluid was mainly constituted of $\mathrm{CO}_{2}(66.9 \mathrm{~mol} \%$ at $1 \mathrm{GPa}$ and $800^{\circ} \mathrm{C}$, FMQ; $73.7 \mathrm{~mol} \%$ at $3 \mathrm{GPa}$ and $800^{\circ} \mathrm{C}$, FMQ) and $\mathrm{H}_{2} \mathrm{O}\left(25.5 \mathrm{~mol} \%\right.$ at $3 \mathrm{GPa}$ and $800^{\circ} \mathrm{C}$, FMQ; $32.3 \mathrm{~mol} \%$ at $1 \mathrm{GPa}$ and $\left.800^{\circ} \mathrm{C}, \mathrm{FMQ}\right)$. However, the volatile speciation of $\mathrm{COH}$ fluids coexisting with either quartz-coesite $\left(\mathrm{SiO}_{2}-\right.$ $\mathrm{COH}$ system) or forsterite + enstatite $\left(\mathrm{MgO}-\mathrm{SiO}_{2}-\mathrm{COH}\right.$ system) clearly displayed a significant increase in $\mathrm{XCO}_{2}$ compared to experiments in which silicates were not present (Fig. 2).

The amount of $\mathrm{CO}_{2}$ was up to $+28 \%\left(\mathrm{SiO}_{2}-\mathrm{COH}\right)$ and $+33 \%\left(\mathrm{MgO}-\mathrm{SiO}_{2}-\mathrm{COH}\right)$ at $1 \mathrm{GPa}$ and $800{ }^{\circ} \mathrm{C}$ and $+9 \%$ $\left(\mathrm{SiO}_{2}-\mathrm{COH}\right)$ at $3 \mathrm{GPa}$ and $800^{\circ} \mathrm{C}$ in experiments buffered by FMQ buffer. In experiments buffered by $\mathrm{NNO}$ at $1 \mathrm{GPa}$ and $800^{\circ} \mathrm{C}$ the measured increased was $+14 \%\left(\mathrm{SiO}_{2}-\mathrm{COH}\right)$ and $+15 \%\left(\mathrm{MgO}-\mathrm{SiO}_{2}-\mathrm{COH}\right)$. Since the run products showed no evidence of hydration and/or carbonation reactions, the observed $\mathrm{CO}_{2}$ increase was attributed to an effect of graphite and silicate dissolution reactions. As a matter of fact, if graphite is present in excess, silicate dissolution can modify the fluid speciation in both systems, $\mathrm{SiO}_{2}-\mathrm{COH}$ and $\mathrm{MgO}-$ $\mathrm{SiO}_{2}-\mathrm{COH}$, as a consequence of a decrease in water activity 


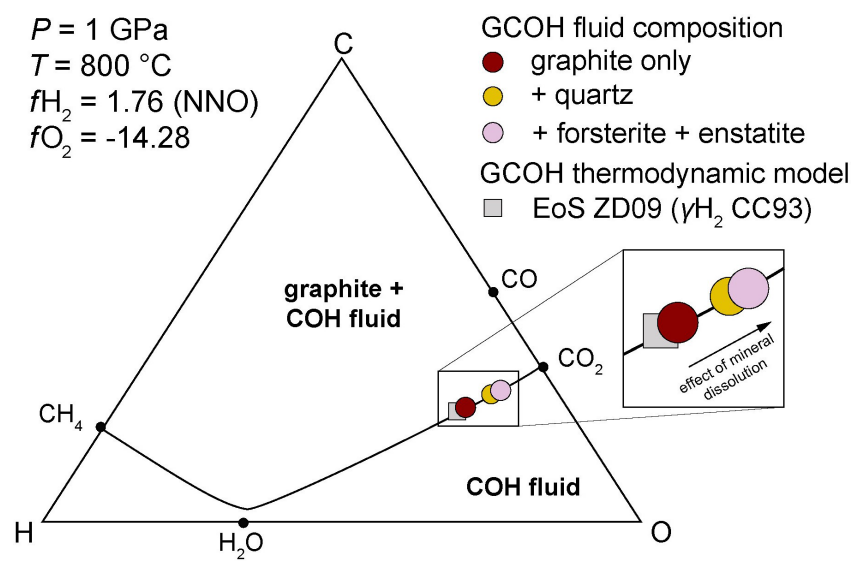

Figure 2. Measured $\mathrm{COH}$ volatile composition of graphitesaturated fluids interacting with silicates at $1 \mathrm{GPa}$ and $800^{\circ} \mathrm{C}$ and $f \mathrm{H}_{2}$ buffered by NNO, modified from Tumiati et al. (2017). The volatile composition of fluid was measured through quadrupole mass spectrometry (Tiraboschi et al., 2016) in equilibrium with graphite only, graphite + quartz, and graphite + forsterite + enstatite. In the diagram is also reported the graphite saturation surface (solid black line) and the volatile fluid composition predicted by the EoS of Zhang and Duan (2009) using the $\mathrm{H}_{2}$ fugacity coefficient of Connolly and Cesare (1993). In the zoomed-in box the effect of silicate dissolution is highlighted. Oxygen and hydrogen fugacity values are reported as $\log f \mathrm{O}_{2}$ and $\log f \mathrm{H}_{2}$.

associated with the formation of organic complexes containing $\mathrm{Si}-\mathrm{O}-\mathrm{C}$ and $\mathrm{Si}-\mathrm{O}-\mathrm{Mg}$ bonds.

The combined results from volatile speciation, coupled with mineral dissolution data (see Sect. 3), suggest that the silica component derived from the dissolution of either magnesium silicates (Tiraboschi et al., 2018) or quartz/coesite alone (Tumiati et al., 2017) controls the composition of deep $\mathrm{COH}$ fluids in equilibrium with graphite, in particular enhancing their $\mathrm{CO}_{2}$ content when compared to $\mathrm{SiO}_{2}$-free systems due to the polymerized nature of silica at high pressures and temperatures (Newton and Manning, 2009). This effect can be relevant for subduction mélanges, in which silicate minerals and graphite are thought to be abundant and flushed by aqueous fluids, originating from the dehydration of the subducted lithosphere. The dissolution of silicates can boost graphite oxidation in the subduction mélange in the form of volatile $\mathrm{CO}_{2}$ dissolved in $\mathrm{COH}$ fluids by up to $+30 \%$ compared to silicate-free systems, independently from the occurrence of carbonates. These $\mathrm{CO}_{2}$-rich fluids will interact with the overlying mantle rocks, influencing metasomatic processes, carbonation/decarbonation reactions, and the melting temperatures of rocks in the mantle wedge (Tumiati et al., 2017). The effect of $\mathrm{COH}$ fluids on mantle rocks has been also observed in metamorphic blueschist facies rocks from Alpine Corsica and the Western Alps (e.g., Piccoli et al., 2018; Vitale Brovarone et al., 2020), where abundant quartz precipitation in the presence of carbonaceous material and graphite has been attributed to fluid-mediated selective dissolution processes.

\section{Dissolution processes in GCOH fluids}

Studies on mineral solubility over the last 50 years have been essential to define the total amount of solutes derived from a variety of minerals in equilibrium with different fluids. Experimental constraints on mineral solubility in high-pressure fluids are in fact crucial to assess the mass transport of elements operated by fluids at depth. Most solubility studies have been conducted ex situ, meaning that the fluid is extracted and sampled after quenching the experiment from high-pressure and high-temperature conditions (see Sect. 2). Ex situ experiments have targeted major individual phases representative of the subducted oceanic crust, sediments, and the mantle wedge, including quartz (Manning, 1994), calcite (Caciagli and Manning, 2003; Fein and Walther, 1989), and forsterite (Nakamura and Kushiro, 1974; Newton and Manning, 2002). Experimental data on mineral dissolution in mixed $\mathrm{H}_{2} \mathrm{O}-\mathrm{CO}_{2}$ fluids are however far more scarce and up to now only available for a few minerals, such as quartz (Newton and Manning, 2000, 2009; Shmulovich et al., 2006; Walther and Orville, 1983), albite, and diopside (Shmulovich et al., 2001). The results of these studies suggest that the presence of $\mathrm{CO}_{2}$ lowers the solute content in the fluid. In the system $\mathrm{SiO}_{2}-\mathrm{H}_{2} \mathrm{O}-\mathrm{CO}_{2}$, mixed fluids show decreasing amounts of $\mathrm{SiO}_{2}$ with increasing content of $\mathrm{CO}_{2}$ in the fluid (i.e., increasing $\mathrm{XCO}_{2}$ ) and increasing temperatures likely due to the decrease in the activity of water (e.g., Newton and Manning, 2000). However, recent works (Tiraboschi et al., 2018; Tumiati et al., 2017) indicate that in the presence of graphite the amount of solutes increases with increasing temperature and $\mathrm{XCO}_{2}$, suggesting an alternative mechanism for dissolution processes in $\mathrm{COH}$ fluids.

To analyze the solubility of quartz in $\mathrm{H}_{2} \mathrm{O}-\mathrm{CO}_{2}$ mixed fluids, Walther and Orville (1983) developed an extraction quench hydrothermal apparatus. The experiments were performed in cold seal vessels at low-pressure conditions (i.e., $0.2 \mathrm{GPa}$ ) and at $T<600^{\circ} \mathrm{C}$. Results showed a decrease in quartz solubility with increasing amounts of $\mathrm{CO}_{2}$ in the fluid.

Schneider and Eggler (1986) extracted and collected the solutes from piston cylinder experiments performed at 1.5$2 \mathrm{GPa}$ and $600-1100^{\circ} \mathrm{C}$. Solutes were mixed with $\mathrm{LiBO}_{2}$ and fused in graphite capsule at $1000^{\circ} \mathrm{C}$ for $10 \mathrm{~min}$. The resulting glasses were then analyzed through electron microprobe. The solubility of different types of peridotites (amphibole-, phlogopite-, and clinopyroxene-bearing peridotite) and single minerals in mixed $\mathrm{H}_{2} \mathrm{O}-\mathrm{CO}_{2}$ fluids were retrieved. Results showed that the addition of $9 \mathrm{~mol} \%$ of $\mathrm{CO}_{2}$ to the aqueous fluid has a strong effect in depressing the solubility of silicates by approximately 1 order of magnitude.

A modified version of the weight loss technique (Manning, 1994) was employed to determine the activity-composition 
relations in $\mathrm{CO}_{2}-\mathrm{H}_{2} \mathrm{O}$ solutions (Aranovich and Newton, 1999). The capsule was frozen in liquid nitrogen and punctured with a needle while still frozen. The immediate weight loss was ascribed to $\mathrm{CO}_{2}$ escape. The capsules were then dried and reweighed to retrieve the $\mathrm{H}_{2} \mathrm{O}$ content. This technique, applied on double capsules, was also used to investigate quartz dissolution in $\mathrm{H}_{2} \mathrm{O}-\mathrm{CO}_{2}$ fluids at $P=0.2-$ $1.5 \mathrm{GPa}$ and $T=500-900^{\circ} \mathrm{C}$ (Newton and Manning, 2000, 2009). The solubility of $\mathrm{SiO}_{2}$ in the fluid decreased strongly with increasing $\mathrm{CO}_{2}$, in agreement with previous experimental data. Similar results were also retrieved by Shmulovich et al. (2001, 2006), which investigated quartz and albite solubilities at $0.9 \mathrm{GPa}$ and $800^{\circ} \mathrm{C}$ by measuring the weight change in single crystals using the rapid-quench method modified from Manning (1994).

A more recent experimental study by Tiraboschi et al. (2018) showed that the solubility of silicate minerals such as forsterite and enstatite in graphite-saturated $\mathrm{H}_{2} \mathrm{O}-\mathrm{CO}_{2}$ fluids is significantly higher compared to systems containing only $\mathrm{H}_{2} \mathrm{O}$ as the volatile component (Newton and Manning, 2002). Solubility experiments were conducted from 1 to $2.1 \mathrm{GPa}$ and 700 to $1200^{\circ} \mathrm{C}$ using a rocking piston cylinder apparatus. Redox conditions were buffered by NNO employing the double capsule technique (Eugster, 1957; Eugster et al., 1966). The dissolved solute loads were analyzed through a modified version of the cryogenic LA-ICP-MS (laser ablation inductively coupled plasma mass spectrometry) technique (Aerts et al., 2010; Kessel et al., 2004), employed for the first time on redox-buffered $\mathrm{COH}$ fluids. The results showed that forsterite + enstatite solubility in GCOH fluids is higher compared to pure water, both in terms of dissolved $\mathrm{SiO}_{2}$ and $\mathrm{MgO}$ (Fig. 3). The enhanced solubility in $\mathrm{GCOH}$ fluids, compared to pure water was related to the formation of $\mathrm{C}-, \mathrm{Mg}-$, and Si-bearing organic complexes, as suggested by thermodynamic calculations applying the DEW model (Sverjensky et al., 2014b). The effect of graphite-saturated $\mathrm{COH}$ fluids on the solubility of forsterite and enstatite was extendible to other systems such as $\mathrm{SiO}_{2}+\mathrm{GCOH}$ fluid (Tumiati et al., 2017). The measured $\mathrm{Si}$ content at $1 \mathrm{GPa}$ and $800^{\circ} \mathrm{C}$ was lower than quartz solubility in pure water at the same conditions (Manning, 1994). However, the value was much higher than reported solubilities in graphite-free $\mathrm{H}_{2} \mathrm{O}-$ $\mathrm{CO}_{2}$ fluids with similar $\mathrm{XCO}_{2}$ (Newton and Manning, 2000, 2009) (Fig. 3).

The cryogenic LA-ICP-MS technique was also employed to investigate carbonate dissolution in GCOH fluids. The solubility of magnesite associated with enstatite has been investigated at $1.5 \mathrm{GPa}$ and at temperatures of 800 and $900^{\circ} \mathrm{C}$ (Tiraboschi et al., 2018). The amount of solutes derived from the dissolution of magnesite + enstatite in a GCOH fluid was comparable to the experimental data from Caciagli and Manning (2003) relative to calcite dissolution in $\mathrm{H}_{2} \mathrm{O}$ by considering $\mathrm{Mg}$ and $\mathrm{Si}$ as dissolved cations instead of $\mathrm{Ca}$. Solute amounts for $\mathrm{Mg}$ and $\mathrm{Ca}$ were observed to be similar, sug- gesting an analogous behavior for calcite and magnesite at the investigated conditions.

\section{Crystalline graphite vs. glass-like carbon dissolution}

For a comprehensive characterization of GCOH fluids it is pivotal to address also the solid carbon phase in equilibrium with the $\mathrm{COH}$ fluid. In experiments, crystalline graphite is employed at pressures ranging from lower-crust to uppermantle conditions (e.g., Tumiati et al., 2017) to represent ordered carbonaceous materials in subduction zone sedimentary rocks. Other forms of carbon, such as glass-like carbon, can be also employed as a proxy for disordered carbonaceous material (e.g., Tumiati et al., 2020). Glass-like carbon, also known as glassy carbon, is a non-crystalline and nongraphitizing carbon, which will not develop graphite crystals up to $3000^{\circ} \mathrm{C}$ at room pressure and up to $45 \mathrm{GPa}$ at room temperature (Shiell et al., 2018). This form of amorphous carbon is considered an inert phase which will not react with the experimental assemblages and therefore can also serve as fluid/melt trap (e.g., Van Den Bleeken et al., 2010; Borghini et al., 2018; Dasgupta et al., 2005; Falloon et al., 2008; Robinson et al., 1998; Spandler et al., 2008; Wasylenki et al., 2003).

In principle, carbon saturation in $\mathrm{COH}$ fluids can be achieved by adding any carbon solid phases, from crystalline graphite to glassy carbon and diamond. However, one of the assumptions to calculate the volatile speciation of GCOH fluids through conventional thermodynamic modeling (see Sect. 1.1) is that graphite should be perfectly ordered. As a consequence, the volatile speciation of $\mathrm{COH}$ fluids in equilibrium with different forms of graphite, such as glass-like carbon, should be experimentally evaluated case by case. Moreover, investigating how different forms of carbon dissolve in aqueous and more complex fluids is fundamental to unravel how organic matter can be mobilized from the subducting slab to the mantle wedge.

Recently, Tumiati et al. (2020) investigated the dissolution of glass-like carbon and crystalline graphite in aqueous fluids at $800{ }^{\circ} \mathrm{C}$ and pressures of 1 and $3 \mathrm{GPa}$. Crystalline graphite was employed to represent the behavior of ordered carbon, while glass-like carbon was considered as an analogue for disordered graphitic carbon. Solid carbon was analyzed through scanning electron microscope (SEM), micro-Raman spectroscopy, and synchrotron X-ray diffraction, while GCOH fluids were characterized employing the capsule-piercing QMS technique (Tiraboschi et al., 2016).

At the investigated experimental $P-T-f \mathrm{O}_{2}$ conditions (NNO and FMQ buffers in double capsules), the dominant dissolution product was carbon dioxide, formed by the oxidation of solid carbon. At $1 \mathrm{GPa}$ and $800{ }^{\circ} \mathrm{C}$, oxidative dissolution of glass-like carbon produced $16-19 \mathrm{~mol} \%$ more $\mathrm{CO}_{2}$ than crystalline graphite (Fig. 4). The $\mathrm{COH}$ volatile speciation in equilibrium with glass-like carbon consisted 


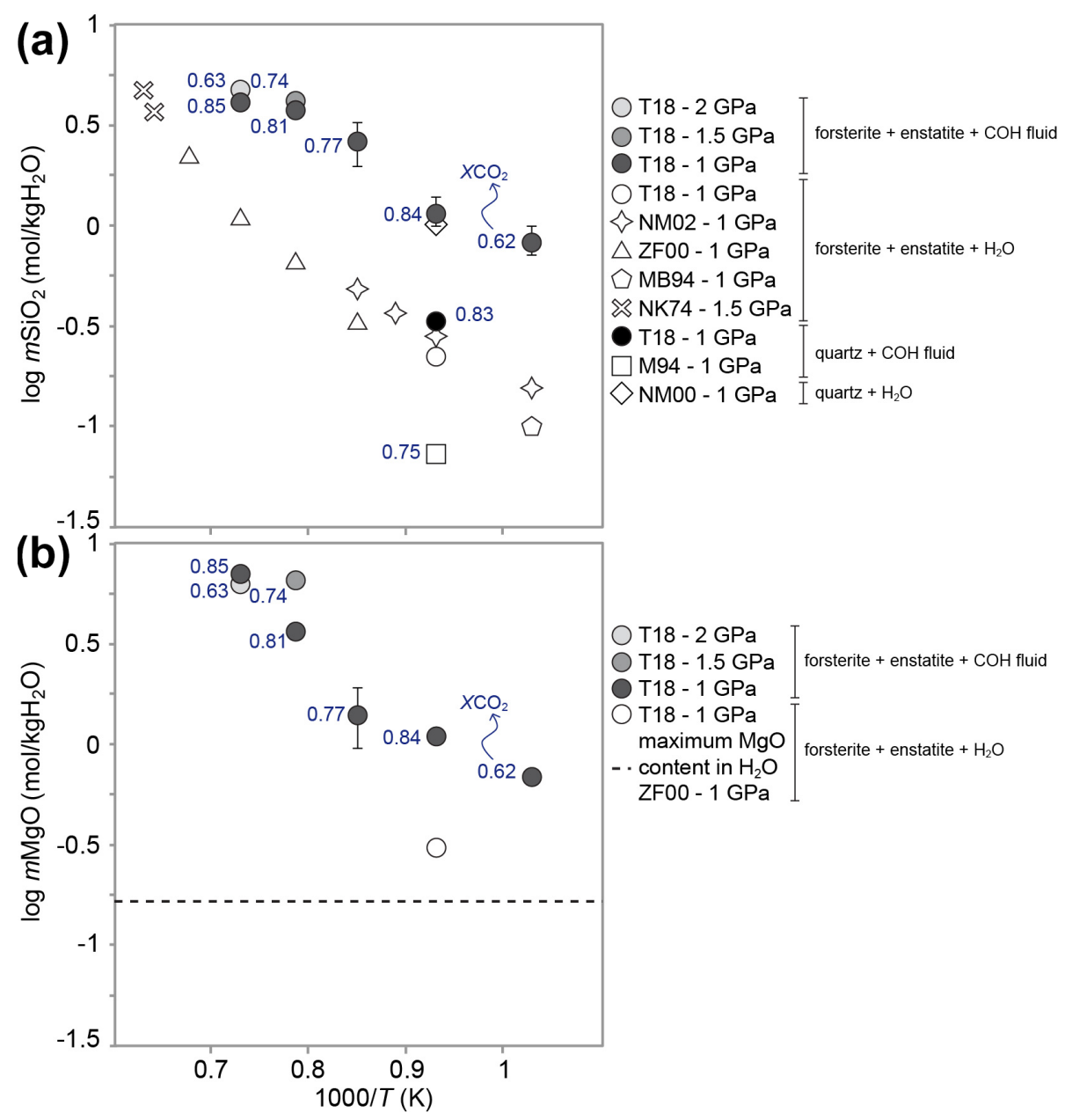

Figure 3. $\mathrm{SiO}_{2}$ (a) and $\mathrm{MgO}$ (b) contents (expressed as mol per kg of water) in $\mathrm{GCOH}$ fluids and $\mathrm{H}_{2} \mathrm{O}$-only fluids as a function of inverse temperature at $P=1-2 \mathrm{GPa}$ and $T=700-1100^{\circ} \mathrm{C}$, modified from Tiraboschi et al. (2018). The $X \mathrm{CO}_{2}$ of the coexisting COH fluid is also reported. T18: Tiraboschi et al. (2018); NM02: Newton and Manning (2002); ZF00: Zhang and Frantz (2000); MB94: Manning and Boettcher (1994); NK74: Nakamura and Kushiro (1974); M94: Manning (1994); NM00: Newton and Manning (2000).

in $5.03 \mathrm{mmol}$ of $\mathrm{CO}_{2}$ and $0.89 \mathrm{mmol}$ of $\mathrm{H}_{2} \mathrm{O}$ at $\mathrm{NNO}$ conditions $\left(\mathrm{XCO}_{2}=0.85\right)$, while in equilibrium with crystalline graphite the generated fluid was $4.87 \mathrm{mmol} \mathrm{CO}_{2}$ and $1.80 \mathrm{mmol} \mathrm{H}_{2} \mathrm{O}\left(X \mathrm{CO}_{2}=0.73\right)$. Similarly, $\mathrm{COH}$ fluids at FMQ conditions exhibited a difference in $\mathrm{XCO}_{2}$, from 0.80 when in equilibrium with glass-like carbon to 0.67 in equilibrium with crystalline graphite. In contrast, fluids interacting with glass-like carbon at $3 \mathrm{GPa}$ showed only a limited increase in $\mathrm{CO}_{2}\left(X \mathrm{CO}_{2}=0.10 ; \mathrm{NNO}\right)$ or even a lower $\mathrm{CO}_{2}$ content $\left(\mathrm{XCO}_{2}=0.57\right.$; FMQ $)$ with respect to fluids interacting with crystalline graphite $\left(X_{2}=0.10\right.$ for $\mathrm{NNO}$ and $X \mathrm{CO}_{2}=0.74$ for FMQ).

The discrepancies in the dissolution behavior were ascribable to differences in the thermodynamic properties of glasslike carbon and crystalline graphite (i.e., higher compressibility of glass-like carbon, differences in Gibbs free energy). As a result, disordered graphitic carbon appeared to be more prone to oxidation relative to ordered crystalline graphite, leading to fluids enriched in $\mathrm{CO}_{2}$ with respect to current estimates. The experimental data indicated that, in the presence of aqueous fluids that flush subducted sediments, the removal of poorly crystalline disordered graphitic carbon is more efficient than that of crystalline graphite (Fig. 5).

This occurs especially at shallow levels of subduction zones, where the difference in free energy between crystalline and disordered graphitic carbon is higher (i.e., $+1.7(1) \mathrm{kJ} \mathrm{mol}^{-1}$ at $1 \mathrm{GPa}-800^{\circ} \mathrm{C}$ and $+0.51(1) \mathrm{kJ} \mathrm{mol}^{-1}$ at $3 \mathrm{GPa}-800^{\circ} \mathrm{C}$; see Tumiati et al., 2020) and the availability of poorly organized metastable carbonaceous matter and of aqueous fluids is maximized. The different dissolution susceptibility declines at pressure corresponding to $110 \mathrm{~km}$ in depth, where glass-like carbon is thought to be less soluble than crystalline graphite. This seems to be supported by ultra-high-pressure eclogitic and metasedimentary rocks from Cignana Lake in the Western Alps (Frezzotti, 2019; Frezzotti et al., 2014), which show the preservation 


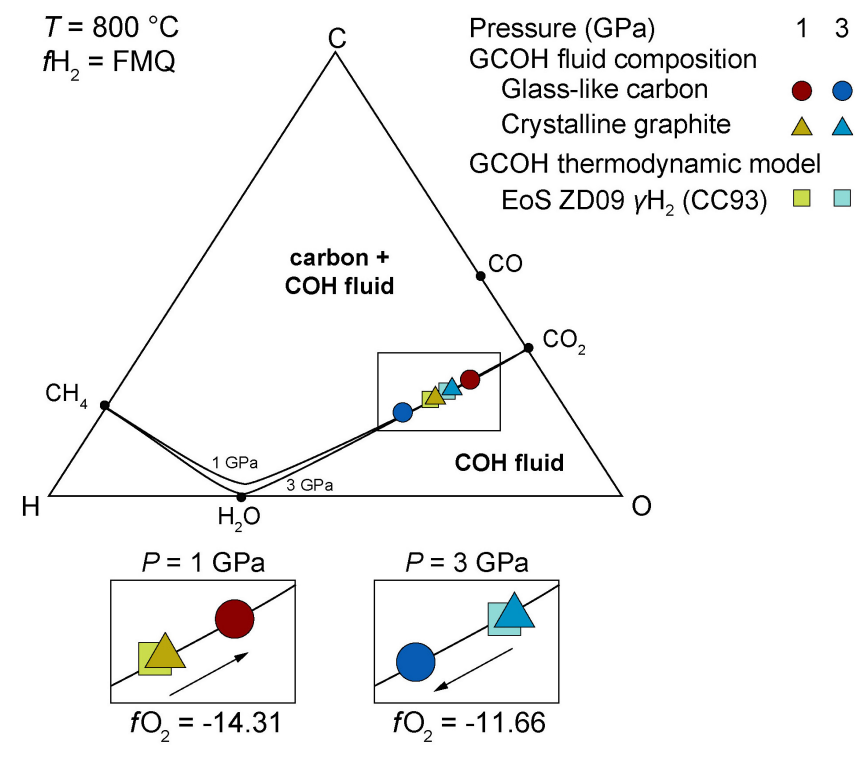

Figure 4. Measured volatile composition of carbon-saturated fluids at $1-3 \mathrm{GPa}$ and $800^{\circ} \mathrm{C}$ and $f \mathrm{H}_{2}$ buffered by FMQ buffer, modified from Tumiati et al. (2020). The volatile compositions were measured through quadrupole mass spectrometry (Tiraboschi et al., 2016) in equilibrium with crystalline graphite (triangles) and glasslike carbon (dots). In the diagram are also reported the two graphite saturation surfaces (solid black lines) at 1 and $3 \mathrm{GPa}$, together with the volatile fluid composition predicted by the EoS of Zhang and Duan (2009) using the $\mathrm{H}_{2}$ fugacity coefficient of Connolly and Cesare (1993) (squares). In the zoom boxes the different dissolution susceptibility of ordered and disordered graphitic carbon in aqueous fluids is highlighted at 1 and at $3 \mathrm{GPa}$. Oxygen fugacity values are reported as $\log f \mathrm{O}_{2}$.

of nano-crystalline disordered graphitic carbon in microand nano-sized diamonds. As glass-like carbon had been synthetized at diamond-stable conditions (i.e., $7.7 \mathrm{GPa}$ and $1000^{\circ} \mathrm{C}$ ) (Yamaoka et al., 2002), further experimental work is vital to evaluate its role at ultra-high-pressure conditions (i.e., $>5 \mathrm{GPa}$ ).

\section{Conclusions}

The results summarized in this contribution emphasize how pivotal it is to quantitatively assess the volatile speciation in carbon-saturated $\mathrm{COH}$ fluid experiments. Even though conventional thermodynamic modeling represents a valuable tool to predict the volatile speciation at certain $P, T$, and $f \mathrm{O}_{2}$ conditions, care must be taken to extend the calculation to more complex systems.

The presence of silicates in equilibrium with GCOH fluid can significantly modify the speciation of volatiles mainly due to the generation of solute species, leading to significant differences between the calculated and the actual volatile speciation. Nevertheless, the mechanism controlling the solubility of silicate minerals is poorly understood, and experi-

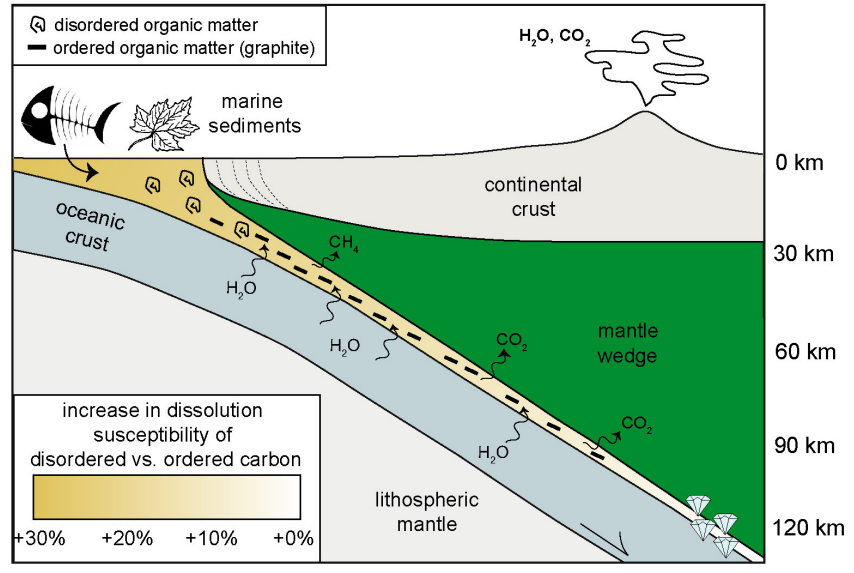

Figure 5. Cartoon showing the fate of organic carbon in subduction zones modified from Tumiati et al. (2020). Ordered and disordered organic carbon is brought into subduction and is subject to increasing temperatures, leading to an increase in crystallinity of disordered matter. In the forearc region, at low-pressure conditions, disordered carbon is more prone to oxidation compared to ordered graphite. At these conditions, a flush of water would dissolve preferably disordered organic matter from the subducted sediments, while graphite will be more refractory. As subduction proceeds this different behavior will vanish at about $100 \mathrm{~km}$ depth, where the free energy of graphite and disordered carbon will become similar.

mental in situ confirmation of the formation and stability of the anticipated solute species in $\mathrm{COH}$ fluids is still missing. Likewise, the mechanism governing how graphite enhances the solute budget of GCOH fluids should be characterized, especially at conditions relevant to fluid processes in subduction zones, where graphite is a major carbon-bearing species.

The interactions generated by the presence of GCOH fluid in the subduction zone lead to significant modifications in the subduction mélange and in the overlying mantle wedge (Fig. 6), enhancing the amount of $\mathrm{CO}_{2}$ in the fluid and prompting metasomatic processes. Additional constraints are thus required to further calibrate thermodynamic models which also include charged species, such as the DEW model (Sverjensky et al., 2014b), and assess the complex dynamic of subduction zones. Recently, thanks to solubility data on simple and multicomponent systems, the DEW model has been extended (Huang and Sverjensky, 2019) to incorporate new equilibrium constants for aqueous bisilicate anion, silica trimer, silicate complexes of $\mathrm{Ca}, \mathrm{Fe}, \mathrm{Al}$, and $\mathrm{Mg}$, and formate complexes of $\mathrm{Fe}$ and $\mathrm{Ca}$, providing new constraints to model fluid-rock interactions at upper-mantle conditions.

Investigating other carbon-bearing phases, such as carbonates, is another pivotal step in GCOH fluids studies. Carbonates represent a significant source of carbon at lower-crust and upper-mantle conditions (Caciagli and Manning, 2003). Extrapolated thermodynamic data indicate that at $1 \mathrm{GPa}$ and 500 to $750^{\circ} \mathrm{C}$ the dominant dissolved carbon species is $\mathrm{CO}_{2}$ (Caciagli and Manning, 2003), while at higher pres- 


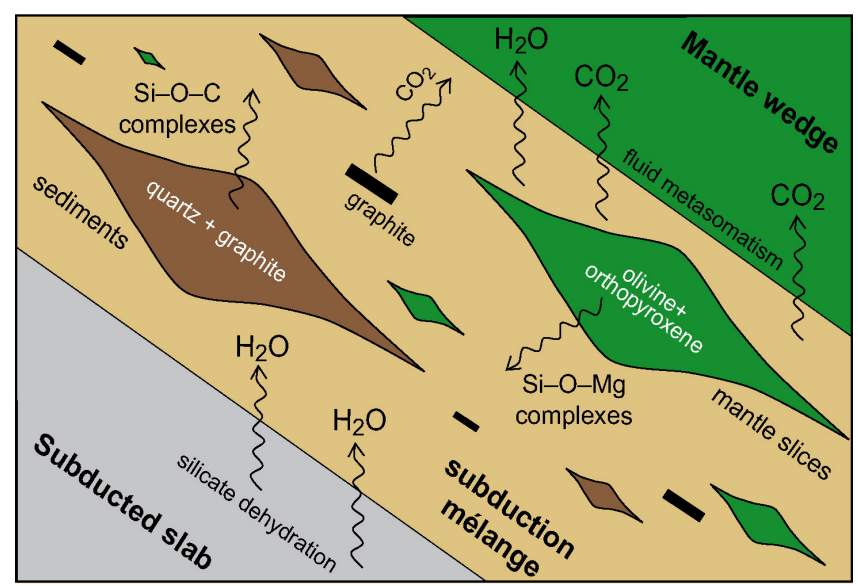

Figure 6. Cartoon showing a subduction mélange modified from Tumiati et al. (2017). The aqueous fluids released from the subducted slab interact with slices of mantle-derived rocks (forsterite + enstatite) and sedimentary slab cover (quartz + graphite). Silicates dissolution in GCOH fluids and the consequent release of organosilicon complexes enhance the $\mathrm{CO}_{2}$ content in the fluid. These $\mathrm{CO}_{2}$ and solute-rich fluids will subsequently interact with the mantle wedge, prompting metasomatic processes.

sure conditions the main carbon-carrier species is $\mathrm{CO}_{3}^{2-}$ (Pan et al., 2013). Quantitative analyses on the generation of Cbearing fluids would represent a significant step forward in understanding the contribution of carbonate dissolution to the global deep carbon cycle. Similarly, assessing the effect of diamond on $\mathrm{COH}$ fluid speciation will bring additional constraints to the carbon cycling at ultra-high-pressure conditions. Eventually, reducing oxygen fugacity conditions should be also evaluated to explore the genesis of $\mathrm{CH}_{4}$-rich fluids and their influence on silicate dissolution.

A joint effort from several geoscience branches and from ex situ and in situ experiments to thermodynamic modeling, assisted by evidence from natural samples, is then pivotal to fully characterize $\mathrm{COH}$ fluids and understand their behavior at upper-mantle conditions.

Data availability. Data sharing is not applicable to this article as no datasets were generated or analyzed for this review.

Author contributions. CT and FM wrote the review. ST supervised the process.

Competing interests. The contact author has declared that neither they nor their co-authors have any competing interests.
Disclaimer. Publisher's note: Copernicus Publications remains neutral with regard to jurisdictional claims in published maps and institutional affiliations.

Special issue statement. This article is part of the special issue "Probing the Earth: experiments and mineral physics at mantle depths". It is not associated with a conference.

Acknowledgements. Reviews from Vincenzo Stagno and an anonymous reviewer significantly improved the manuscript. Monika Koch-Müller and Elisabetta Rampone are acknowledged for the editorial handling.

Financial support. This research has been supported by the Ministero dell'Istruzione, dell'Università e della Ricerca (grant no. 2017ZE49E7_002). Carla Tiraboschi has been supported by the Wire fellowship from WWU Münster (Germany).

Review statement. This paper was edited by Monika Koch-Müller and reviewed by Vincenzo Stagno and one anonymous referee.

\section{References}

Aerts, M., Hack, A. C., Reusser, E., and Ulmer, P.: Assessment of the diamond-trap method for studying high-pressure fluids and melts and an improved freezing stage design for laser ablation ICP-MS analysis, Am. Mineral., 95, 1523-1526, 2010.

Akaishi, M. and Yamaoka, S.: Crystallization of diamond from C$\mathrm{O}-\mathrm{H}$ fluids under high-pressure and high-temperature conditions, J. Cryst. Growth, 209, 999-1003, https://doi.org/10.1016/S00220248(99)00756-3, 2000.

Akaishi, M., Shaji Kumar, M. D., Kanda, K., and Yamaoka, S.: Formation process of diamond from supercritical $\mathrm{H}_{2} \mathrm{O}-\mathrm{CO}_{2}$ fluid under high pressure and high temperature conditions, Diam. Relat. Mater., 9, 1945-1950, https://doi.org/10.1016/S09259635(00)00366-6, 2000.

Andersen, T. and Neumann, E. R.: Fluid inclusions in mantle xenoliths, Lithos, 55, 301-320, https://doi.org/10.1016/S00244937(00)00049-9, 2001.

Aoya, M., Kouketsu, Y., Endo, S., Shimizu, H., Mizukami, T., Nakamura, D., and Wallis, S.: Extending the applicability of the Raman carbonaceous-material geothermometer using data from contact metamorphic rocks, J. Metamorph. Geol., 28(9), 895914, https://doi.org/10.1111/j.1525-1314.2010.00896.x, 2010.

Aranovich, L. Y. and Newton, R. C.: $\mathrm{H}_{2} \mathrm{O}$ activity in concentrated $\mathrm{KCl}$ and $\mathrm{KCl}-\mathrm{NaCl}$ solutions at high temperatures and pressures measured by the brucite-periclase equilibrium, Contrib. Mineral. Petr., 127, 261-271, https://doi.org/10.1007/s004100050279, 1997.

Aranovich, L. Y. and Newton, R. C.: Experimental determination of $\mathrm{CO}_{2}-\mathrm{H}_{2} \mathrm{O}$ activity-composition relations at $600-1000{ }^{\circ} \mathrm{C}$ and $6-14$ kbar by reversed decarbonation and dehydration reactions, 
Am. Mineral., 84, 1319-1332, https://doi.org/10.2138/am-19990908, 1999.

Baker, M. B. and Stolper, E. M.: The composition of high-pressure mantle melts: results from diamond aggregate experiments, Mineral. Mag., 58, 44-45, 1994.

Ballhaus, C., Berry, R. F., and Green, D. H.: High pressure experimental calibration of the olivine-orthopyroxene-spinel oxygen geobarometer: implications for the oxidation state of the upper mantle, Contrib. Mineral. Petr., 107, 27-40, 1991.

Balta, J. B., Beckett, J. R., and Asimow, P. D.: Thermodynamic properties of alloys of gold-74/palladium-26 with variable amounts of iron and the use of Au-Pd-Fe alloys as containers for experimental petrology, Am. Mineral., 96, 1467-1474, https://doi.org/10.2138/am.2011.3637, 2011.

Bassett, W. A., Shen, A. H., Bucknum, M. and Chou, I. M.: A new diamond anvil cell for hydrothermal studies to $2.5 \mathrm{GPa}$ and from -190 to $1200^{\circ} \mathrm{C}$, Rev. Sci. Instrum., 64, 2340-2345, https://doi.org/10.1063/1.1143931, 1993.

Beyssac, O. and Rumble, D.: Graphitic carbon: A ubiquitous, diverse, and useful geomaterial, Elements, 10, 415-420, https://doi.org/10.2113/gselements.10.6.415, 2014.

Beyssac, O., Rouzaud, J. N., Goffé, B., Brunet, F., and Chopin, C.: Graphitization in a high-pressure, low-temperature metamorphic gradient: A Raman microspectroscopy and HRTEM study, Contrib. Mineral. Petr., 143, 19-31, https://doi.org/10.1007/s00410001-0324-7, 2002.

Boettcher, A. L., Mysen, B. O., and Allen, J. C.: Techniques for the control of water fugacity and oxygen fugacity for experimentation in solid-media high-pressure apparatus, J. Geophys. Res., 78, 5898-5901, https://doi.org/10.1029/jb078i026p05898, 1973.

Borghini, G., Francomme, J. E., and Fumagalli, P.: Melt-dunite interactions at 0.5 and $0.7 \mathrm{GPa}$ : experimental constraints on the origin of olivine-rich troctolites, Lithos, 323, 44-57, https://doi.org/10.1016/j.lithos.2018.09.022, 2018.

Bowers, T. S. and Helgeson, H. C.: Calculation of the thermodynamic and geochemical consequences of nonideal mixing in the system $\mathrm{H}_{2} \mathrm{O}-\mathrm{CO}_{2}-\mathrm{NaCl}$ on phase relations in geologic systems: Equation of state for $\mathrm{H}_{2} \mathrm{O}-\mathrm{CO}_{2}-\mathrm{NaCl}$ fluids at high pressures and temperatures, Geochim. Cosmochim. Ac., 47, 1247-1275, https://doi.org/10.1016/0016-7037(83)90066-2, 1983.

Caciagli, N. C. and Manning, C. E.: The solubility of calcite in water at 6-16 kbar and $500-800^{\circ} \mathrm{C}$, Contrib. Mineral. Petr., 146, 275-285, https://doi.org/10.1007/s00410-003-0501-y, 2003.

Chepurov, A. I., Tomilenko, A. A., Zhimulev, E. I., Sonin, V. M., Chepurov, A. A., Kovyazin, S. V., Timina, T. Y., and Surkov, N. V.: The conservation of an aqueous fluid in inclusions in minerals and their interstices at high pressures and temperatures during the decomposition of antigorite, Russ. Geol. Geophys., 53, 234-246, https://doi.org/10.1016/j.rgg.2012.02.002, 2012.

Connolly, J. A. D.: Phase diagram methods for graphitic rocks and application to the system $\mathrm{C}-\mathrm{O}-\mathrm{H}-\mathrm{FeO}-\mathrm{TiO}_{2}-\mathrm{SiO}_{2}$, Contrib. Mineral. Petr., 119, 94-116, https://doi.org/10.1007/BF00310720, 1995.

Connolly, J. A. D. and Cesare, B.: C-O-H-S fluid composition and oxygen fugacity in graphitic metapelites, J. Metamorph. Geol., 11, 379-388, https://doi.org/10.1111/j.15251314.1993.tb00155.x, 1993.

Dasgupta, R., Hirschmann, M. M., and Dellas, N.: The effect of bulk composition on the solidus of carbonated eclogite from partial melting experiments at $3 \mathrm{GPa}$, Contrib. Mineral. Petr., 149, 288 305, https://doi.org/10.1007/s00410-004-0649-0, 2005.

Day, H. W.: A revised diamond-graphite transition curve, Am. Mineral., 97, 52-62, https://doi.org/10.2138/am.2011.3763, 2012.

Dvir, O. and Kessel, R.: The effect of $\mathrm{CO}_{2}$ on the watersaturated solidus of $\mathrm{K}$-poor peridotite between 4 and $6 \mathrm{GPa}$, Geochim. Cosmochim. Ac., 206, 184-200, https://doi.org/10.1016/j.gca.2017.02.028, 2017.

Dvir, O., Angert, A., and Kessel, R.: Determining the composition of C-H-O liquids following high-pressure and high-temperature diamond-trap experiments, Contrib. Mineral. Petr., 165, 593599, https://doi.org/10.1007/s00410-012-0825-6, 2013.

Eggler, D. H., Mysen, B. O., Hoering, T. C., and Holloway, J. R.: The solubility of carbon monoxide in silicate melts at high pressures and its effect on silicate phase relations, Earth Planet. Sc. Lett., 43, 321-330, 1979.

Eugster, H. P.: Heterogeneous reactions involving oxidation and reduction at high pressures and temperatures, J. Chem. Phys., 26, 1761-1762, https://doi.org/10.1063/1.1743626, 1957.

Eugster, H. P. and Skippen, G. B.: Igneous and metamorphic reactions involving gas equilibria, Res. Geochem., 2, 492-520, 1967.

Eugster, H. P., Skippen, G. B., and Huebner, J. S.: Experimental buffering systems for the control of gas fugacities in complex gas mixtures, Eos T. Am. Geophys. Un., 47, 211, 1966.

Facq, S., Daniel, I., Montagnac, G., Cardon, H., and Sverjensky, D. A.: In situ Raman study and thermodynamic model of aqueous carbonate speciation in equilibrium with aragonite under subduction zone conditions, Geochim. Cosmochim. Ac., 132, 375-390, https://doi.org/10.1016/j.gca.2014.01.030, 2014.

Falloon, T. J., Green, D. H., Danyushevsky, L. V., and Mcneill, A. W.: The composition of near-solidus partial melts of fertile peridotite at 1 and $1.5 \mathrm{GPa}$ : Implications for the petrogenesis of MORB, J. Petrol., 49, 591-613, https://doi.org/10.1093/petrology/egn009, 2008.

Fein, J. B. and Walther, J. V.: Calcite solubility and speciation in supercritical $\mathrm{NaCl}-\mathrm{HCl}$ aqueous fluids, Contrib. Mineral. Petr., 103, 317-324, https://doi.org/10.1007/BF00402918, 1989.

French, B. M.: Some geological implications of equilibrium between graphite and a $\mathrm{C}-\mathrm{H}-\mathrm{O}$ gas phase at high temperatures and pressures, Rev. Geophys., 4, 223-253, https://doi.org/10.1029/RG004i002p00223, 1966.

Frezzotti, M. L.: Diamond growth from organic compounds in hydrous fluids deep within the Earth, Nat. Commun., 10, 1-8, https://doi.org/10.1038/s41467-019-12984-y, 2019.

Frezzotti, M. L. and Touret, J. L. R.: $\mathrm{CO}_{2}$, carbonate-rich melts, and brines in the mantle, Geosci. Front., 5, 697-710, https://doi.org/10.1016/j.gsf.2014.03.014, 2014.

Frezzotti, M. L., Tecce, F., and Casagli, A.: Raman spectroscopy for fluid inclusion analysis, J. Geochem. Explor., 112, 1-20, https://doi.org/10.1016/j.gexplo.2011.09.009, 2012.

Frezzotti, M. L., Huizenga, J. M., Compagnoni, R., and Selverstone, J.: Diamond formation by carbon saturation in $\mathrm{C}-\mathrm{O}-\mathrm{H}$ fluids during cold subduction of oceanic lithosphere, Geochim. Cosmochim. Ac., 143, 68-86, https://doi.org/10.1016/j.gca.2013.12.022, 2014.

Fried, L. E. and Howard, W. M.: Explicit Gibbs free energy equation of state applied to the carbon phase diagram, Phys. Rev. B, 61, 8734, https://doi.org/10.1103/PhysRevB.61.8734, 2000. 
Frost, D. J. and McCammon, C. A.: The Redox State of Earth's Mantle, Annu. Rev. Earth Pl. Sc., 36, 389-420, https://doi.org/10.1146/annurev.earth.36.031207.124322, 2008.

Galvez, M. E., Manning, C. E., Connolly, J. A. D., and Rumble, D.: The solubility of rocks in metamorphic fluids: A model for rock-dominated conditions to upper mantle pressure and temperature, Earth Planet. Sc. Lett., 430, 486-498, https://doi.org/10.1016/j.epsl.2015.06.019, 2015.

Goncharov, A. G. and Ionov, D. A.: Redox state of deep off-craton lithospheric mantle: New data from garnet and spinel peridotites from Vitim, southern Siberia, Contrib. Mineral. Petr., 164, 731745, https://doi.org/10.1007/s00410-012-0767-z, 2012.

Green, D. H.: Experimental melting studies on a model upper mantle composition at high pressure under water-saturated and waterundersaturated conditions, Earth Planet. Sc. Lett., 19, 37-53, https://doi.org/10.1016/0012-821X(73)90176-3, 1973.

Hammouda, T. and Keshav, S.: Melting in the mantle in the presence of carbon: Review of experiments and discussion on the origin of carbonatites, Chem. Geol., 418, 171-188, https://doi.org/10.1016/j.chemgeo.2015.05.018, 2015.

Hirose, K. and Kushiro, I.: Partial melting of dry peridotites at high pressures: Determination of compositions of melts segregated from peridotite using aggregates of diamond, Earth Planet. Sc. Lett., 114, 477-489, https://doi.org/10.1016/0012821X(93)90077-M, 1993.

Holland, H. D.: Some applications of thermochemical data to problems of ore deposits II, Mineral assemblages and the composition of ore-forming fluids, Econ. Geol., 60, 1101-1166, https://doi.org/10.2113/gsecongeo.60.6.1101, 1965.

Holloway, J. R.: Graphite- $\mathrm{CH}_{4}-\mathrm{H}_{2} \mathrm{O}-\mathrm{CO}_{2}$ equilibria at low-grade metamorphic conditions, Geology, 12, 455-458, 1984.

Holloway, J. R., Burnham, C. W., and Millhollen, G. L.: Generation of $\mathrm{H}_{2} \mathrm{O}-\mathrm{CO}_{2}$ mixtures for use in hydrothermal experimentation, J. Geophys. Res., 73, 6598-6600, 1968.

Holloway, J. R. and Jakobsson, S.: Volatile solubilities in magmas: transport of volatiles from mantles to planet surfaces, J. Geophys. Res.-Sol. Ea., 91, 505-508, 1986.

Holloway, J. R. and Reese, R. L.: The generation of $\mathrm{N}_{2}-\mathrm{CO}_{2}-\mathrm{H}_{2} \mathrm{O}$ fluids for use in hydrothermal experimentation, I. Experimental method and equilibrium calculations in the COHN system, Am. Mineral. J. Earth Planet. Mater., 59, 587-597, 1974.

Huang, F. and Sverjensky, D. A.: Extended Deep Earth Water Model for predicting major element mantle metasomatism, Geochim. Cosmochim. Ac., 254, 192-230, https://doi.org/10.1016/j.gca.2019.03.027, 2019.

Huebner, J. S.: Buffering Techniques for Hydrostatic Systems at Elevated Pressures, in: Research Techniques for High Pressure and High Temperature, Springer, Berlin, Heidelberg, 123-177, https://doi.org/10.1007/978-3-642-88097-1_5, 1971.

Huizenga, J. M.: Thermodynamic modelling of C-O-H fluids, Lithos, 55, 101-114, https://doi.org/10.1016/S00244937(00)00040-2, 2001.

Huizenga, J. M.: Thermodynamic modelling of a cooling C-O-H fluid-graphite system: Implications for hydrothermal graphite precipitation, Miner. Deposita, 46, 23-33, https://doi.org/10.1007/s00126-010-0310-y, 2011.

Jakobsson, S. and Holloway, J. R.: Crystal-Liquid experiments in the presence of a $\mathrm{COH}$ fluid buffered by graphite+ iron+ wustite: experimental method and near-liquidus relations in basanite, J. Volcanol. Geotherm. Res., 29, 265-291, 1986.

Jakobsson, S. and Oskarsson, N.: Experimental determination of fluid compositions in the system $\mathrm{C}-\mathrm{O}-\mathrm{H}$ at high $\mathrm{P}$ and $\mathrm{T}$ and low fo2, Geochim. Cosmochim. Ac., 54, 355-362, https://doi.org/10.1016/0016-7037(90)90324-E, 1990.

Jakobsson, S. and Oskarsson, N.: The system C-O in equilibrium with graphite at high pressure and temperature: An experimental study, Geochim. Cosmochim. Ac., 58, 9-17, https://doi.org/10.1016/0016-7037(94)90442-1, 1994.

Kawamoto, T., Kobayashi, T., Yoshikawa, M., Kumagai, Y., Mirabueno, M. H. T., and Okuno, M.: Mantle wedge infiltrated with saline fluids from dehydration and decarbonation of subducting slab, P. Natl. Acad. Sci. USA, 110, 9663-9668, https://doi.org/10.1073/pnas.1302040110, 2013.

Kessel, R., Ulmer, P., Pettke, T., Schmidt, M. W., and Thompson, A. B.: A novel approach to determine highpressure high-temperature fluid and melt compositions using diamond-trap experiments, Am. Mineral., 89, 1078-1086, https://doi.org/10.2138/am-2004-0720, 2004.

Kogiso, T., Tatsumi, Y., and Nakano, S.: Trace element transport during dehydration processes in the subducted oceanic crust: 1. Experiments and implications for the origin of ocean island basalts, Earth Planet. Sc. Lett., 148, 193-205, https://doi.org/10.1016/s0012-821x(97)00018-6, 1997.

Labotka, T. C.: Chemical and physical properties of fluids, Rev. Mineral., 26, 42-104, 1991.

Lamadrid, H. M., Lamb, W. M., Santosh, M., and Bodnar, R. J.: Raman spectroscopic characterization of $\mathrm{H}_{2} \mathrm{O}$ in $\mathrm{CO}_{2}$-rich fluid inclusions in granulite facies metamorphic rocks, Gondwana Res., 26, 301-310, https://doi.org/10.1016/j.gr.2013.07.003, 2014.

$\mathrm{Li}$, Y.: Immiscible $\mathrm{C}-\mathrm{H}-\mathrm{O}$ fluids formed at subduction zone conditions, Geochem. Perspect. Lett., 3, 12-21, https://doi.org/10.7185/geochemlet.1702, 2017.

Louvel, M., Sanchez-Valle, C., Malfait, W. J., Testemale, D., and Hazemann, J. L.: $\mathrm{Zr}$ complexation in high pressure fluids and silicate melts and implications for the mobilization of HFSE in subduction zones, Geochim. Cosmochim. Ac. 104, 281-299, https://doi.org/10.1016/j.gca.2012.11.001, 2013.

Luth, R. W.: Natural versus experimental control of oxidation-stateeffects on the composition and speciation of C-O-H fluids, Am. Mineral., 74, 50-57, 1989.

Malaspina, N. and Tumiati, S.: The role of C-O-H and oxygen fugacity in subduction-zone garnet peridotites, Eur. J. Mineral., 24, 607-618, https://doi.org/10.1127/0935-1221/2012/0024-2213, 2012.

Malaspina, N., Scambelluri, M., Poli, S., Van Roermund, H. L. M., and Langenhorst, F.: The oxidation state of mantle wedge majoritic garnet websterites metasomatised by Cbearing subduction fluids, Earth Planet. Sc. Lett., 298, 417-426, https://doi.org/10.1016/j.epsl.2010.08.022, 2010.

Manning, C.: The solubility of quartz in $\mathrm{H}_{2} \mathrm{O}$ in the lower crust and upper mantle, Geochim. Cosmochim. Ac., 58, 4831-4839, 1994

Manning, C. E.: The chemistry of subductionzone fluids, Earth Planet. Sc. Lett., 223, 1-16, https://doi.org/10.1016/j.eps1.2004.04.030, 2004.

Manning, C. E. and Boettcher, S. L.: Rapid-quench hydrothermal experiments at mantle pressures and temperatures, Am. Mineral., 79, 1153-1158, 1994. 
Manning, C. E., Shock, E. L., and Sverjensky, D. A.: The Chemistry of Carbon in Aqueous Fluids at Crustal and Upper-Mantle Conditions: Experimental and Theoretical Constraints, Rev. Mineral. Geochem., 75, 109-148, https://doi.org/10.2138/rmg.2013.75.5, 2013.

Marschall, H. R. and Schumacher, J. C.: Arc magmas sourced from mélange diapirs in subduction zones, Nat. Geosci., 5, 862-867, https://doi.org/10.1038/ngeo1634, 2012.

Martin, L. A. J. and Hermann, J.: Experimental phase relations in altered oceanic crust: Implications for carbon recycling at subduction zones, J. Petrol., 59, 299-320, https://doi.org/10.1093/petrology/egy031, 2018.

Mason, E., Edmonds, M., and Turchyn, A. V: Dominate Volcanic Arc Emissions, Science, 294, 290-294, 2017.

Matveev, S., Ballhaus, C., Fricke, K., Truckenbrodt, J., and Ziegenben, D.: Volatiles in the earth's mantle: I. Synthesis of CHO fluids at $1273 \mathrm{~K}$ and $2.4 \mathrm{GPa}$, Geochim. Cosmochim. Ac., 61, 30813088, 1997.

McCubbin, F. M., Sverjensky, D. A., Steele, A., and Mysen, B. O.: In-situ characterization of oxalic acid breakdown at elevated $\mathrm{P}$ and $\mathrm{T}$ : Implications for organic $\mathrm{C}-\mathrm{O}-\mathrm{H}$ fluid sources in petrologic experiments, Am. Mineral., 99, 2258-2271, https://doi.org/10.2138/am-2014-4947, 2014.

Menzel, M. D., Garrido, C. J., and López Sánchez-Vizcaíno, V.: Fluid-mediated carbon release from serpentinite-hosted carbonates during dehydration of antigorite-serpentinite in subduction zones, Earth Planet. Sc. Lett., 531, 115964, https://doi.org/10.1016/j.eps1.2019.115964, 2020.

Miozzi, F. and Tumiati, S.: Aqueous concentration of $\mathrm{CO}$ in carbon-saturated fluids as a highly sensitive oxybarometer, Geochem. Perspect. Lett., 16, 30-34, https://doi.org/10.7185/geochemlet.2040, 2020.

Mookherjee, M., Keppler, H., and Manning, C. E.: Aluminum speciation in aqueous fluids at deep crustal pressure and temperature, Geochim. Cosmochim. Ac., 133, 128-141, https://doi.org/10.1016/j.gca.2014.02.016, 2014.

Morgan, G. B., Chou, I. M., and Pasteris, J. D.: Speciation in experimental C-O-H fluids produced by the thermal dissociation of oxalic acid dihydrate, Geochim. Cosmochim. Ac., 56, 281-294, https://doi.org/10.1016/0016-7037(92)90133-4, 1992.

Mysen, B. O. and Yamashita, S.: Speciation of reduced C-O-H volatiles in coexisting fluids and silicate melts determined in-situ to $\sim 1.4 \mathrm{GPa}$ and $800^{\circ} \mathrm{C}$, Geochim. Cosmochim. Ac., 74, 45774588, https://doi.org/10.1016/j.gca.2010.05.004, 2010.

Nakamura, Y. and Kushiro, I.: Composition of the gas phase in $\mathrm{Mg}_{2} \mathrm{SiO}_{4}-\mathrm{SiO}_{2}-\mathrm{H}_{2} \mathrm{O}$ at $15 \mathrm{kbar}$, Carnegie Inst. Washingt. Yearb., 73, 255-258, 1974.

Newton, R. C. and Manning, C. E.: Quartz solubility in $\mathrm{H}_{2} \mathrm{O}-\mathrm{NaCl}$ and and $\mathrm{H}_{2} \mathrm{O}-\mathrm{CO}_{2}$ solutions at deep crust-upper mantle pressures and temperatures: $2-15 \mathrm{kbar}$ and $500-900^{\circ} \mathrm{C}$, Geochim. Cosmochim. Ac., 64, 2993-3005, 2000.

Newton, R. C. and Manning, C. E.: Solubility of enstatite + forsterite in $\mathrm{H}_{2} \mathrm{O}$ at deep crust/upper mantle conditions: 4 to $15 \mathrm{kbar}$ and 700 to $900^{\circ} \mathrm{C}$, Geochim. Cosmochim. Ac., 66, 4165-4176, https://doi.org/10.1016/S0016-7037(02)00998$5,2002$.

Newton, R. C. and Manning, C. E.: Hydration state and activity of aqueous silica in $\mathrm{H}_{2} \mathrm{O}-\mathrm{CO}_{2}$ fluids at high pressure and temperature, Am. Mineral., 94, 1287-1290, https://doi.org/10.2138/am.2009.3287, 2009.

Ohmoto, H. and Kerrick, D. M.: Devolatilization equilibria in graphitic systems, Am. J. Sci., 277, 1013-1044, https://doi.org/10.2475/ajs.277.8.1013, 1977.

Pan, D. and Galli, G.: The fate of carbon dioxide in waterrich fluids under extreme conditions, Sci. Adv., 2, e1601278, https://doi.org/10.1126/sciadv.1601278, 2016.

Pan, D., Spanu, L., Harrison, B., Sverjensky, D. A., and Galli, G.: Dielectric properties of water under extreme conditions and transport of carbonates in the deep Earth, P. Natl. Acad. Sci. USA, 110, 6646-6650, https://doi.org/10.1073/pnas.1221581110, 2013.

Pasteris, J. D. and Wanamaker, B. J.: Laser Raman microprobe analysis of experimentally re-equilibrated fluid inclusions in olivine: Some implications for mantle fluids, Am. Mineral., 73, 1074 1088, 1988.

Pawley, A. R., Holloway, J. R., and McMillan, P. F.: The effect of oxygen fugacity on the solubility of carbon-oxygen fluids in basaltic melt, Earth Planet. Sc. Lett., 110, 213-225, https://doi.org/10.1016/0012-821X(92)90049-2, 1992.

Piccoli, F., Vitale Brovarone, A., and Ague, J. J.: Field and petrological study of metasomatism and high-pressure carbonation from lawsonite eclogite-facies terrains, Alpine Corsica, Lithos, 304307, 16-37, https://doi.org/10.1016/j.lithos.2018.01.026, 2018.

Poli, S.: Carbon mobilized at shallow depths in subduction zones by carbonatitic liquids - supplementary information, Nat. Geosci., 8, 633-636, https://doi.org/10.1038/ngeo2464, 2015.

Poli, S. and Schmidt, M. W.: Petrology of Subducted Slabs, Annu. Rev. Earth Pl. Sc., 30, 207-235, https://doi.org/10.1146/annurev.earth.30.091201.140550, 2002.

Poli, S., Franzolin, E., Fumagalli, P., and Crottini, A.: The transport of carbon and hydrogen in subducted oceanic crust: An experimental study to $5 \mathrm{GPa}$, Earth Planet. Sc. Lett., 278, 350-360, https://doi.org/10.1016/j.epsl.2008.12.022, 2009.

Redlich, O. and Kwong, J. N.: On the thermodynamics of solutions, $\mathrm{V}$, An equation of state, Fugacities of gaseous solutions, Chem. Rev., 44, 233-244, 1948.

Robinson, J. A. C., Wood, B. J., and Blundy, J. D.: The beginning of melting of fertile and depleted peridotite at $1.5 \mathrm{GPa}$, Earth Planet. Sc. Lett., 155, 97-111, https://doi.org/10.1016/s0012821x(97)00162-3, 1998.

Roedder, E.: Liquid $\mathrm{CO}_{2}$ inclusions in olivine-bearing nodules and phenocrysts from basalts, Am. Mineral., 50, 1746-1782, 1965.

Rosenbaum, J. M. and Slagel, M. M.: COH speciation in pistoncylinder experiments, Am. Mineral., 80, 109-114, 1995.

Sanchez-Valle, C.: Structure and Thermodynamics of Subduction Zone Fluids from Spectroscopic Studies, Rev. Mineral. Geochem., 76, 265-309, https://doi.org/10.2138/rmg.2013.76.8, 2013.

Sanchez-Valle, C., Martinez, I., Daniel, I., Philippot, P., Bohic, S., and Simionovici, A.: Dissolution of strontianite at high P-T conditions: An in-situ synchrotron X-ray fluorescence study, Am. Mineral., 88, 978-985, https://doi.org/10.2138/am-2003-0705, 2003.

Scambelluri, M. and Philippot, P.: Deep fluids in subduction zones, Lithos, 55, 213-227, https://doi.org/10.1016/S00244937(00)00046-3, 2001. 
Scambelluri, M., Vannucci, R., De Stefano, A., Preite-Martinez, M., and Rivalenti, G.: $\mathrm{CO}_{2}$ fluid and silicate glass as monitors of alkali basalt/peridotite interaction in the mantle wedge beneath Gobernador Gregores, Southern Patagonia, Lithos, 107, 121133, https://doi.org/10.1016/j.lithos.2008.06.015, 2009.

Schmidt, C.: Raman spectroscopic determination of carbon speciation and quartz solubility in $\mathrm{H}_{2} \mathrm{O}+\mathrm{Na}_{2} \mathrm{CO}_{3}$ and $\mathrm{H}_{2} \mathrm{O}+$ $\mathrm{NaHCO}_{3}$ fluids to $600^{\circ} \mathrm{C}$ and $1.53 \mathrm{GPa}$, Geochim. Cosmochim. Ac., 145, 281-296, https://doi.org/10.1016/j.gca.2014.09.009, 2014.

Schmidt, C. and Chou, I. M.: The hydrothermal diamond anvil cell (HDAC) for Raman spectroscopic studies of geological fluids at high pressures and temperatures, Eur. Mineral. Union Notes Mineral., 12, 249-278, https://doi.org/10.1180/EMU-notes.12.7, 2012.

Schmidt, M. W. and Poli, S.: Devolatilisation During Subduction, Treatise on Geochemistry, 4, 669-701, 2014.

Schneider, M. E. and Eggler, D. H.: Fluids in equilibrium with peridotite minerals: Implications for mantle metasomatism, Geochim. Cosmochim. Ac., 50, 711-724, https://doi.org/10.1016/0016-7037(86)90347-9, 1986.

Shiell, T. B., McCulloch, D. G., McKenzie, D. R., Field, M. R., Haberl, B., Boehler, R., Cook, B. A., De Tomas, C., Suarez-Martinez, I., Marks, N. A., and Bradby, J. E.: Graphitization of Glassy Carbon after Compression at Room Temperature, Phys. Rev. Lett., 120, 215701, https://doi.org/10.1103/PhysRevLett.120.215701, 2018.

Shmulovich, K., Graham, C., and Yardley, B.: Quartz, albite and diopside solubilities in $\mathrm{H}_{2} \mathrm{O}-\mathrm{NaCl}$ and $\mathrm{H}_{2} \mathrm{O}-\mathrm{CO}_{2}$ fluids at $0.5-0.9 \mathrm{GPa}$, Contrib. Mineral. Petr., 141, 95-108, https://doi.org/10.1007/s004100000224, 2001.

Shmulovich, K. I., Yardley, B. W. D., and Graham, C. M.: Solubility of quartz in crustal fluids: Experiments and general equations for salt solutions and $\mathrm{H}_{2} \mathrm{O}-\mathrm{CO}_{2}$ mixtures at $400-800^{\circ} \mathrm{C}$ and $0.1-$ $0.9 \mathrm{GPa}$, Geofluids, 6, 154-167, https://doi.org/10.1111/j.14688123.2006.00140.x, 2006.

Sieber, M. J., Hermann, J., and Yaxley, G. M.: An experimental investigation of $\mathrm{C}-\mathrm{O}-\mathrm{H}$ fluid-driven carbonation of serpentinites under forearc conditions, Earth Planet. Sc. Lett., 496, 178-188, https://doi.org/10.1016/j.eps1.2018.05.027, 2018.

Sieber, M. J., Yaxley, G. M., and Hermann, J.: Investigation of Fluid-driven Carbonation of a Hydrated, Forearc Mantle Wedge using Serpentinite Cores in High-pressure Experiments, J. Petrol., 61, egaa035, https://doi.org/10.1093/petrology/egaa035, 2020.

Sokol, A. G., Tomilenko, A. A., Bul'Bak, T. A., Palyanova, G. A., Sokol, I. A., and Palyanov, Y. N.: Carbon and Nitrogen Speciation in N-poor C-O-H-N Fluids at $6.3 \mathrm{GPa}$ and $1100-1400^{\circ} \mathrm{C}$, Sci. Rep., 7, 1-19, https://doi.org/10.1038/s41598-017-00679-7, 2017a.

Sokol, A. G., Palyanov, Y. N., Tomilenko, A. A., Bul'bak, T. A., and Palyanova, G. A.: Carbon and nitrogen speciation in nitrogenrich C-O-H-N fluids at 5.5-7.8 GPa, Earth Planet. Sc. Lett., 460, 234-243, https://doi.org/10.1016/j.epsl.2016.11.050, 2017b.

Sokol, E., Kozmenko, O., Smirnov, S., Sokol, I., Novikova, S., Tomilenko, A., Kokh, S., Ryazanova, T., Reutsky, V., Bul'bak, T., Vapnik, Y., and Deyak, M.: Geochemical assessment of hydrocarbon migration phenomena: Case studies from the south- western margin of the Dead Sea Basin, J. Asian Earth Sci., 93, 211-228, https://doi.org/10.1016/j.jseaes.2014.07.023, 2014.

Spandler, C., Yaxley, G., Green, D. H., and Rosenthal, A.: Phase relations and melting of anhydrous k-bearing eclogite from 1200 to $1600{ }^{\circ} \mathrm{C}$ and 3 to $5 \mathrm{GPa}$, J. Petrol., 49, 771-795, https://doi.org/10.1093/petrology/egm039, 2008.

Stagno, V.: Carbon, carbides, carbonates and carbonatitic melts in the earth's interior, J. Geol. Soc. London, 176, 375-387, https://doi.org/10.1144/jgs2018-095, 2019.

Stagno, V. and Frost, D. J.: Carbon speciation in the asthenosphere: Experimental measurements of the redox conditions at which carbonate-bearing melts coexist with graphite or diamond in peridotite assemblages, Earth Planet. Sc. Lett., 300, 72-84, https://doi.org/10.1016/j.epsl.2010.09.038, 2010.

Sverjensky, D. A., Stagno, V., and Huang, F.: Important role for organic carbon in subduction-zone fluids in the deep carbon cycle, Nat. Geosci., 7, 909-913, https://doi.org/10.1038/ngeo2291, $2014 a$.

Sverjensky, D. A., Harrison, B., and Azzolini, D.: Water in the deep Earth: The dielectric constant and the solubilities of quartz and corundum to $60 \mathrm{~kb}$ and $1200^{\circ} \mathrm{C}$, Geochim. Cosmochim. Ac., 129, 125-145, https://doi.org/10.1016/j.gca.2013.12.019, 2014b.

Tao, R. B., Zhang, L. F., Stagno, V., Chu, X., and Liu, X.: High-pressure experimental verification of rutile-ilmenite oxybarometer: Implications for the redox state of the subduction zone, Sci. China Earth Sci., 60, 1817-1825, https://doi.org/10.1007/s11430-016-9082-5, 2017.

Tatsumi, Y., Hamilton, D. L., and Nesbitt, R. W.: Chemical characteristics of fluid phase released from a subducted lithosphere and origin of arc magmas: Evidence from high-pressure experiments and natural rocks, J. Volcanol. Geoth. Res., 29, 293-309, https://doi.org/10.1016/0377-0273(86)90049-1, 1986.

Taylor, S. R. and McLennan, S. M.: The geochemical evolution of the continental crust, Rev. Geophys., 33, 241-265, https://doi.org/10.1029/95RG00262, 1995.

Taylor, W. R. and Foley, S. F.: Improved oxygen-buffering techniques for $\mathrm{C}-\mathrm{O}-\mathrm{H}$ fluid-saturated experiments at high pressure, J. Geophys. Res., 94, 4146-4158, https://doi.org/10.1029/JB094iB04p04146, 1989.

Taylor, W. R. and Green, D. H.: The petrogenetic role of methane: effect on liquidus phase relations and the solubility mechanism of reduced C-H volatiles, Magmat. Process. Physicochem. Princ., 1, 121-138, 1987.

Taylor, W. R. and Green, D. H.: Measurement of reduced peridotiteC-O-H solidus and implications for redox melting of the mantle, Nature, 332, 349-352, https://doi.org/10.1038/332349a0, 1988.

Tiraboschi, C., Tumiati, S., Recchia, S., Miozzi, F., and Poli, S.: Quantitative analysis of $\mathrm{COH}$ fluids synthesized at HP-HT conditions: an optimized methodology to measure volatiles in experimental capsules, Geofluids, 16, 841-855, https://doi.org/10.1111/gfl.12191, 2016.

Tiraboschi, C., Tumiati, S., Sverjensky, D., Pettke, T., Ulmer, P., and Poli, S.: Experimental determination of magnesia and silica solubilities in graphite-saturated and redox-buffered highpressure $\mathrm{COH}$ fluids in equilibrium with forsterite + enstatite and magnesite + enstatite, Contrib. Mineral. Petr., 173, 1-17, https://doi.org/10.1007/s00410-017-1427-0, 2018. 
Truckenbrodt, J. and Johannes, W.: $\mathrm{H}_{2} \mathrm{O}$ loss during pistoncylinder experiments, Am. Mineral., 84, 1333-1335, https://doi.org/10.2138/am-1999-0909, 1999.

Truckenbrodt, J., Ziegenbein, D., and Johannes, W.: Redox conditions in piston-cylinder apparatus: The different behavior of boron nitride and unfired pyrophyllite assemblies, Am. Mineral., 82, 337-344, https://doi.org/10.2138/am-1997-3-412, 1997.

Tumiati, S., Fumagalli, P., Tiraboschi, C., and Poli, S.: An experimental study on COH-bearing peridotite up to $3 \cdot 2 \mathrm{GPa}$ and implications for crust-mantle recycling, J. Petrol., 54, 453-479, https://doi.org/10.1093/petrology/egs074, 2013.

Tumiati, S., Tiraboschi, C., Sverjensky, D. A., Pettke, T., Recchia, S., Ulmer, P., Miozzi, F., and Poli, S.: Silicate dissolution boosts the $\mathrm{CO}_{2}$ concentrations in subduction fluids, Nat. Commun., 8, 1-11, https://doi.org/10.1038/s41467-017-00562-z, 2017.

Tumiati, S., Tiraboschi, C., Miozzi, F., Vitale-Brovarone, A., Manning, C. E., Sverjensky, D. A., Milani, S., and Poli, S.: Dissolution susceptibility of glass-like carbon versus crystalline graphite in high-pressure aqueous fluids and implications for the behavior of organic matter in subduction zones, Geochim. Cosmochim. Ac., 273, 383-402, https://doi.org/10.1016/j.gca.2020.01.030, 2020.

Van Den Bleeken, G., Müntener, O., and Ulmer, P.: Reaction processes between tholeiitic melt and residual peridotite in the uppermost mantle: An experimental study at $0.8 \mathrm{GPa}$, J. Petrol., 51, 153-183, https://doi.org/10.1093/petrology/egp066, 2010.

Vitale Brovarone, A., Tumiati, S., Piccoli, F., Ague, J. J., Connolly, J. A. D., and Beyssac, O.: Fluid-mediated selective dissolution of subducting carbonaceous material: Implications for carbon recycling and fluid fluxes at forearc depths, Chem. Geol., 549, 119682, https://doi.org/10.1016/j.chemgeo.2020.119682, 2020.

Wallace, P. J.: Volatiles in subduction zone magmas: Concentrations and fluxes based on melt inclusion and volcanic gas data, J. Volcanol. Geoth. Res., 140, 217-240, https://doi.org/10.1016/j.jvolgeores.2004.07.023, 2005.
Walther, J. V. and Orville, P. M.: The extraction-quench technique for determination of the thermodynamic properties of solute complexes: application to quartz solubility in fluid mixtures, Am. Mineral., 68, 731-741, 1983.

Wasylenki, L. E., Baker, M. B., Kent, A. J. R., and Stolper, E. M.: Near-solidus melting of the Shallow Upper Mantle: Partial melting experiments on depleted peridotite, J. Petrol., 44, 1163-1191, https://doi.org/10.1093/petrology/44.7.1163, 2003.

Wilke, M., Schmidt, C., Dubrail, J., Appel, K., Borchert, M., Kvashnina, K. and Manning, C. E.: Zircon solubility and zirconium complexation in $\mathrm{H}_{2} \mathrm{O}+\mathrm{Na}_{2} \mathrm{O}+\mathrm{SiO}_{2} \pm \mathrm{Al}_{2} \mathrm{O}_{3}$ fluids at high pressure and temperature, Earth Planet. Sc. Lett., 349-350, 15-25, https://doi.org/10.1016/j.epsl.2012.06.054, 2012.

Woodland, A. B. and Koch, M.: Variation in oxygen fugacity with depth in the upper mantle beneath the Kaapvaal craton, Southern Africa, Earth Planet. Sc. Lett., 214, 295-310, https://doi.org/10.1016/S0012-821X(03)00379-0, 2003.

Woodland, A. B. and O'Neill, H. S. C.: Thermodynamic data for Fe-bearing phases obtained using noble metal alloys as redox sensors, Geochim. Cosmochim. Ac., 61, 4359-4366, https://doi.org/10.1016/S0016-7037(97)00247-0, 1997.

Yamaoka, S., Shaji Kumar, M. D., Kanda, H., and Akaishi, M.: Crystallization of diamond from $\mathrm{CO}_{2}$ fluid at high pressure and high temperature, J. Cryst. Growth, 234, 5-8, https://doi.org/10.1016/S0022-0248(01)01678-5, 2002.

Zhang, C. and Duan, Z.: A model for C-O-H fluid in the Earth's mantle, Geochim. Cosmochim. Ac., 73, 2089-2102, https://doi.org/10.1016/j.gca.2009.01.021, 2009.

Zhang, Y. G. and Frantz, J. D.: Enstatite-forsterite-water equilibria at elevated temperatures and pressures, Am. Mineral., 85, 918925, https://doi.org/10.2138/am-2000-0705, 2000.

Zotov, N. and Keppler, H.: Silica speciation in aqueous fluids at high pressures and high temperatures, Chem. Geol., 184, 71-82, https://doi.org/10.1016/S0009-2541(01)00353-9, 2002. 